\title{
LAS POLÍTICAS DE LA LENGUA IMPERIAL Y SU RECEPCIÓN EN LA AUDIENCIA DE CHARCAS (SIGLOS XVI-XVIII)*
}

\author{
IMPERIAL POLICIES OF LANGUAGE AND RECEPTION \\ AT THE HEARING OF CHARCAS (XVI-XVIII)
}

\author{
Nelson Castro Flores ${ }^{* *}$ y Jorge Hidalgo Lehuedé****
}

\begin{abstract}
En este artículo se analiza la recepción regional que tuvo las políticas de castellanización de las poblaciones indígenas en la audiencia de Charcas. Entre fines del siglo XVI y la segunda mitad del siglo XVIII, las políticas imperiales castellanizantes abrieron coyunturas administrativas en las que diversos funcionarios civiles y eclesiásticos expresaron sus miradas respecto de la conveniencia de mantener las lenguas indígenas.
\end{abstract}

Palabras claves: Política de la lengua, Audiencia de Charcas, Iglesia colonial, civilidad.

This article analyzes the regional reception of the policies of "castellanización" of indigenous people in the audience of Charcas. Between the late sixteenth century and the second half of the eighteenth century, imperial "castellanizantes" policies opened administrative junctures in which various civil and church officials expressed their views about the desirability of preserving indigenous languages.

Key words: Language policy, Audience of Charcas, colonial church, civility.

\section{Introducción}

Las políticas de castellanización de las poblaciones indígenas, dependientes política y pastoralmente de la Audiencia y del Arzobispado de Charcas respectivamente, han sido consideradas como un componente del ciclo del reformismo borbónico (Hidalgo 2004 [1984]; Hidalgo y Castro 2007). Proceso que Lynch (1996) ha caracterizado como de "imperialismo renovado", y en el que se advierte una reinterpretación de lecturas de viejas propuestas y proyectos imperiales tanto en la monarquía como en sus colonias; ${ }^{1}$ y que, en el caso de la política hacia las lenguas indígenas y de la enseñanza del castellano, tiene en la documentación oficial una extensión que va desde el siglo XVI hasta fines del siglo XVIII (Solano 1992). Sánchez-Albornoz (2006) señala que dicha documentación, particularmente la correspondiente a los siglos XVI y XVII, no evidencia una tendencia explícita a la imposición de la lengua metropolitana ni a la eliminación de las lenguas vernáculas. Si bien en estas materias hubo posiciones encontradas, cada una intentando mostrarse como la mejor adecuación de la voluntad real, no deja de llamar la atención la continuidad secular del proyecto de castellanización de las poblaciones indígenas, aunque indudablemente fueron variando los contextos y las motivaciones de estos proyectos. Precisamente, entre fines del siglo XVI y la segunda mitad del siglo XVIII, los proyectos de castellanización de las poblaciones indígenas abrieron algunas coyunturas administrativas, en el distrito de la audiencia de Charcas, a partir de las cuales es posible analizar las diversas modalidades que adquirió la política de la lengua a lo largo de la situación colonial.

En este sentido, la política de la lengua estuvo tensionada, en una primera etapa, entre las últimas décadas del siglo XVI y la primera mitad del siglo XVIII, por la consideración respecto de la capacidad de las lenguas indígenas para expresar adecuadamente el ordenamiento político y religioso colonial. Aunque no se negaba la legitimidad de la empresa colonial, y de la propia monarquía, como instrumento para la

\footnotetext{
* $\quad$ Resultado proyecto FONDECYT 1130667.

** Universidad Viña del Mar, Viña del Mar, Chile. Correo electrónico: ncastro@uvm.cl

*** Universidad de Chile, Departamento de Ciencias Históricas, Santiago, Chile. Correo electrónico: jorgehidalgolehuede@ gmail.com
} 
conversión y salvación de las almas, sin embargo en el interior de este paradigma salvífico, coexistieron tanto un proyecto de enseñanza en lenguas indígenas como uno de castellanización. Estos proyectos se presentaron, cada uno a su turno, como la mejor adecuación de la voluntad de la monarquía. A pesar que los partidarios de enseñar la doctrina en lengua indígena, realizaron enormes esfuerzos por gramatizar las lenguas indígenas -bajo la consideración que esta reducción a arte gramatical evidenciaba la racionalidad de las lenguas y de quienes las hablaban-, publicaron diccionarios, sermonarios, confesionarios, así como otros instrumentos, no obstante, la variedad cultural y lingüística de las poblaciones indígenas, así como las limitaciones de los propios doctrineros, llevó tempranamente a privilegiar las denominadas lenguas generales en la enseñanza de la doctrina, aprovechando la expansión que aquellas tenían, como es el caso del quechua, en regiones incorporadas al dominio efectivo de la monarquía (Alfaro 2001; Durston 2007; Mannheim 1991; Taylor 1983). Por otra parte, los partidarios de la castellanización vieron en esa variedad lingüística, incluso en las lenguas generales, la peligrosa presencia del demonio con sus nocivos efectos de idolatría, superstición, barbarie e irracionalidad. Todo lo cual ponía en riesgo la salvación de las almas y el ordenamiento político colonial. Además, no debe dejar de considerarse, como lo ha señalado Mannheim, que la inconsistencia en la orientación de la política lingüística en el Virreinato peruano, estuvo estrechamente vinculada "al grupo de presión que tenía la audiencia ante el Consejo" (Mannheim 1989: 19).

En la segunda mitad del siglo XVIII, el proyecto de castellanización de las poblaciones indígenas cobró fuerza, pero bajo una dinámica distinta. En una estrecha alianza de obispos y funcionarios borbónicos, aunados bajo la convicción de fortalecer la monarquía y fomentar las poblaciones, se promovió la erradicación de las lenguas indígenas, a través del establecimiento de escuelas de primeras letras castellanizantes en los pueblos de indios, con el propósito de fomentar las poblaciones y los territorios para asegurar la felicidad de los súbditos (Hidalgo y Castro 2007; Tank de Estrada 1999). En el caso del virreinato peruano, se retomó un proyecto que ya se había diseñado en la década de 1680, por parte del Duque de la Palata, que se perfeccionó hacia 1690, y de cuya implementación, en ese período, se tiene información para el obispado de La Paz. El proyecto de la década de 1770, consideró la incorporación de maestros indígenas ladinos, pero también de criollos, con un financiamiento que debía ser asumida por los pueblos de indios para asegurar su viabilidad y extensión. En este período se visualiza la formulación de una política de la lengua que comparte algunas de las características de las políticas linguíísticas de la Francia revolucionaria, estudiada por Michel de Certeau et al. (2008 [1975]), que alentaron la imposición del francés como lengua apropiada para la comprensión del ideario republicano bajo la consideración que el patois era la lengua de la reacción monárquica.

El análisis de las modalidades que adquirió la recepción de las políticas de la lengua, permite profundizar en el conocimiento de las dinámicas imperiales (Delgado 2007; Cerrón-Palomino 2016), alejados de una comprensión monolítica del sistema colonial español, y explorar tanto la variabilidad como la adaptación regional en el distrito de Charcas colonial. A nivel regional, esto se expresó en las acciones que se emprendieron, desde las últimas décadas del siglo XVI hasta la segunda mitad del siglo XVIII, por virreyes, obispos, arzobispos, curas y corregidores. La documentación colonial, recolectada en estadías de investigación en el Archivo General de Indias, en el Archivo y Biblioteca Nacionales de Bolivia, en el Archivo Eclesiástico del Arzobispado de La Paz y en el Archivo y Biblioteca Arquidiocesanos de Sucre, ha sido analizada bajo la consideración que las dinámicas imperiales, y sus políticas de la lengua, definieron, articularon y tensionaron las iniciativas de las burocracias políticas y religiosas, experimentando interpretaciones y adaptaciones regionales. Precisamente, el análisis de la documentación permite una aproximación, en determinadas coyunturas administrativas, a las modalidades que adquirieron dichos proyectos coloniales y su adaptación a los contextos regionales y locales, así como la recepción que tuvo en los diversos cuerpos burocráticos.

\section{Lengua e Imperio}

Las estrategias de castellanización de las poblaciones indígenas recogieron parte de las tendencias que se registraban en la península, particularmente en la creciente vinculación entre centralismo lingüístico y monarquía. No se trata de un fenómeno exclusivamente hispano, sino que de un aspecto característico de las monarquías europeas del siglo XVI (Calvet 2005). Pero que no debe ser sobredimensionado 
por cuanto el carácter de monarquías compuestas, señala Antonio-Miguel Bernal, impidió, en el siglo XVI, "una imposición forzosa de monolingüismo oficial", aunque esto no significó descartar la idea "que para el Estado moderno una lengua uniforme de gobierno para todos sus dominios era un activo valioso y que significaba un signo de lealtad política el que fuera aceptada por las comunidades de la monarquía" (Bernal 2007: 570). No obstante, agrega Bernal, hubo una serie de conflictos lingüísticos, en los que intervino la monarquía, que decantaron en la castellanización de la península y la universalización del español en el conjunto del imperio.

En las dos últimas décadas del siglo $\mathrm{XV}$, el proyecto político de unificación y reconquista de los territorios ibéricos, promovido por la corona de Castilla, coincidió con el interés que tenían los gramáticos por la palabra y su función mediática. Entre estos, destacó la figura de Antonio de Nebrija, allegado al círculo de consejeros de la reina Isabel, que puede ser considerado como el intelectual de un proyecto de renovación cultural que hizo de la lengua, para retomar a Iannuzi, una "herramienta de trabajo para reformar y homogeneizar la sociedad" (2008: 42). De acuerdo a esta autora, se trató de un cambio de perspectiva en que las preocupaciones de los humanistas, hasta entonces encerrados en un pequeño círculo, se trasladaron y transformaron para responder a las exigencias del poder político ${ }^{2}$. En la dedicatoria de la Gramática Castellana, Antonio de Nebrija retomó la consideración que "siempre la lengua fue compañera del imperio: e de tal manera lo siguio: que juntamente comenzaron, crecieron, e florecieron, e despues junta fue la caida de entrambos" (1744-47 [1492]: s/f). Se trata de una vinculación, establecida por Lorenzo de Valla, para quien el toscano debía ser la lengua imperial que acompañaría la expansión política y territorial de Florencia (Iannuzi 2008: 41) ${ }^{3}$. Entre estos humanistas, había la consideración que el esplendor y decadencia del latín estaba en relación con el esplendor y decadencia del imperio romano (Burke 2006: 29). Tras realizar una breve descripción de esta relación, evocando desde la lengua hebraica hasta el latín imperial, Nebrija señalaba que España se encontraba en una misma situación pues el castellano mostraba sus fuerzas en la literatura y en la extensión de su uso en otros reinos. Además, el sometimiento de "muchos pueblos barbaros e naciones de peregrinas lenguas" obligaba que se les pusiesen leyes "quel vencedor pone al vencido e con ellas nuestra lengua" (1744-47 [1492]: s/f).

A principios del siglo XVII, en su dedicatoria al rey Felipe III, Bernardo de Aldrete señalaba que de la diversidad de lenguas "nacio la diuision, enagenandose los animos i voluntades de los que en la habla no era conformes, i de aquí se siguieron los odios i guerras, estimando como por de diuersa naturaleza a los que en la lengua eran diferentes" (Aldrete 1606: s/f). En la representación de Aldrete, el Imperio Romano fue el instrumento providencial para superar estas divisiones y a través de su lengua aventajada permitió que se uniesen los reinos, "domesticasse los hombres, vniesse los animos i voluntades, desterrase la discordia causada de la diuersidad, i hiziesse en la tierra vn retrato del cielo, para que el Impyreo fuesse mas esclaresido en Dios maravilloso en sus obras, i traças" (Aldrete 1606: s/f). La lengua castellana, del mismo modo que antaño el latín, se había "estendido hasta los vltimos fines del Orbe", y "como hija noble de tan excelente madre le cabe gran parte de su lustre i resplandor".

En su obra, Aldrete incorporó una variada información para probar de qué manera los vencidos recibían la lengua de los vencedores, en un claro intento por demostrar la filiación del castellano con la lengua latina. A través de diversas citas, estableció que esta situación acontecía en todo tiempo y lugar, particularmente en el caso de las Indias Occidentales. Para esto retomó algunos pasajes de la Historia moral de las Indias y De procuranda indorum salutem del padre José de Acosta, además de Pedro Cieza de León, demostrando que en el Perú hubo, y había en ese entonces, una "gran diversidad de lenguas, $i$ tantas que no tienen numero", por lo que "en todo el Imperio de los incas corrio, i corre oi dia mas de mil leguas la lengua que llaman general" (Aldrete 1606: 144). En esta expansión de la lengua general, Aldrete encontraba la prueba de la utilidad que acarreó la introducción de una lengua general, pues ésta había permitido traer paz y amistad entre quienes se consideraban enemigos por hablar distinta lengua. Esta era una buena razón para alentar la expansión del castellano particularmente en las Indias occidentales. Aunque la mayoría de los indios hablaban romance, escribía Aldrete apoyado en testigos que habían estado en las Indias, sin embargo aquellos usaban poco el castellano "por la aficion, que tienen a su lengua, no auiendo quien les obligue a vsar la agena, $i$ algunos tuuieron por pundonor no hablarla" (Aldrete 1606: 
146). Bernardo de Aldrete achacó esta situación a la escasa diligencia que había habido para "la introduccion de la lengua, porque si la vuiera auido, como la pusieron los Romanos, o Guainacapa sin duda en todas ellas se hablara" (Aldrete 1606: 146). Sin embargo, confiaba que de continuar las Indias bajo el gobierno de España en un breve tiempo los indios hablarían castellano sin que fuese necesario introducir ninguna diligencia, como había sucedido con la lengua latina entre los españoles, la general de los incas o la mexicana.

En estas propuestas no es difícil advertir una renovación del programa de promoción del castellano como lengua imperial, en momentos que, como señala Calvet (2005), la centralización lingüística era un instrumento de la centralización política. Pero tampoco se debe dejar de señalar que, en estas propuestas, se asumió una actitud frente a la diversidad de las lenguas que la considera como fuente de confusión y desorden. El imperio y su lengua, fueron considerados como el fundamento de la policía civil y cristiana, el antídoto frente a las costumbres de poblaciones rústicas a las que había que obligar a vivir como hombres. No es de extrañar que posiciones como las de Bernardo de Aldrete hayan sido recogidas por Solórzano Pereira, en su diseño del programa político de la monarquía católica, en el que la lengua está al servicio no solo de una pedagogía del poder político sino que también de un disciplinamiento del cuerpo social.

A diferencia de Bernardo de Aldrete, Juan de Solórzano y Pereira tuvo una experiencia directa en los asuntos de Indias como oidor de la Audiencia de Lima (1610-1627), habiéndosele encargado una recopilación de las leyes de Indias (Bonnet y Castañeda 2006). Hacia 1648, Solórzano Pereira señalaba que en el Consejo de Indias se había debatido dos posturas respecto del problema de las lenguas. Una de estas posturas apuntaba a obligar a los indios a aprender y hablar el castellano, "de tal suerte, que olviden, i dexen del todo las suyas"; la otra postura, suponía el aprendizaje de las lenguas indígenas "para poderles Predicar el Evángelio, i catequizarlos, i comerciar, i negociar con ellos" (Solórzano 1648: 217). Dada la facilidad y conveniencia de la primera postura, Solórzano Pereira se mostró partidario de forzar a los indios a aprender castellano. Aunque indicaba que entre los indios viejos se experimentaría alguna dificultad, no por eso dejarían de aprenderla por la necesidad de entender, sin embargo, "en los muchachos, i en los que después fuesen naciendo, no podia aver, alguna, pues toman, i aprenden con tanta facilidad quantas les quiere enseñar, como lo dize Erasmo" (Solórzano 1648: 218). Estas observaciones de Solórzano, se encontraban apoyadas en una serie de disposiciones reales que ordenaban que los indios aprendiesen castellano, en escuelas a cargo de misioneros, para estrechar su relación con los españoles y para ser instruidos en la fe. Además, consideraba que la supuesta rudeza de los indios no representaba impedimento alguno para aprender la lengua, pues los indios habían aprendido a hablar castellano con cierta perfección y propiedad y, en algunos casos, incluso hasta el latín ${ }^{4}$. En concordancia con su concepción centralizadora del imperio, los planteamientos de Solórzano perseguían "que tambien los obligásemos à q[ue] en el trage i modo de vestir, i en las demas costumbres loables, que no repugnasen à su estado $\mathrm{i}$ codicion, se ajustasen à la de los Españoles, i a su trato, comercio i comunicacion" (Solórzano 1648: 221).

En la diversidad de lenguas indígenas algunos cronistas vieron una confusión demoníaca. Entre otros, el carmelita Antonio Vásquez de Espinoza relacionó la proliferación de lenguas en las Indias con el hecho que sus primeros pobladores, que suponía pertenecientes a las diez tribus de Israel, perdieron su lengua o la mezclaron con vocablos de las naciones con las que entraron en contacto. A esta invención humana, agregaba el carmelita, se añadió "las mañas y astucias del demonio, para causar más confusión, para que no se entendiesen, y de esta suerte tenerlos ciegos y engañados, y con el tiempo la confusión fue en tanto aumento y diversidad de lenguas en aquellas tan extendidas y dilatadas regiones, que pasan de cincuenta mil" (Vásquez de Espinoza 1992: 89). Al igual que en Acosta, Cieza y Bernardo de Aldrete, Vásquez de Espinoza valoró que Manco Cápac hubiese reducido "aquellas fieras salvajinas a mejor modo vida, sacándolos de lo bestial en que estaban por los campos y collados" (Vásquez de Espinoza 1992: 89). De esta forma, se añadía al discurso la representación que la reducción a la razón y a la ley natural se habría provocado por la imposición de la lengua imperial.

La primacía de la lengua imperial también había sido considerada por el Inca Garcilaso de la Vega, aunque con consecuencias distintas de las esperadas por Bernardo de Aldrete, Juan de Solórzano o Antonio Vásquez de Espinoza. Garcilaso de la Vega compartió, con la tradición humanista, que la lengua 
imperial fue inventada para un buen gobierno del imperio de los incas; además, consideró que esto se había realizado por dos razones: para que el inca pudiese comunicarse con sus vasallos y para que su palabra les diera mas satisfacción y consuelo. El cronista mestizo retomó el tópico humanista de la diversidad de la lengua como fuente de enemistad, y valoró la lengua general como un instrumento para domesticar y unir "tanta variedad de naciones diversas y contrarias en idolatrías y costumbre como las que hallaron y sujetaron a su Imperio". La extensión de esta lengua imperial había permitido, a juicio del cronista, que se hablasen y entendiesen "muchas naciones de diferentes lenguas, y por solo ella se han hecho amigos, y confederados donde solían ser enemigos capitales" (Garcilaso de la Vega 2006: 353-354) .

Garcilaso de la Vega no fue el primero en realizar una defensa de la lengua general del Tawantinsuyu. Antes que él, fray Domingo de Santo Tomás había concebido su Gramática o Arte de la lengua general, como un intento de cuestionar, en un prólogo dedicado al rey Felipe II, "quan falso es lo que muchos os han querido persuadir, ser los naturales de los reynos del Peru barbaros, y indignos de ser tractados con la suavidad y libertad que los demas vasallos vuestros lo son" (Domingo de Santo Tomás 1951 [1560]: 9). De acuerdo a Sebastián de Covarrubias, el arte era el orden, razón y concierto de todas las cosas. ${ }^{6}$ La posibilidad que la lengua general pudiese ser reducida a arte, siguiendo el modelo de la gramática latina, evidenciaba, a juicio de fray Domingo de Santo Tomás, "la gran policia que esta lengua tiene". Una vez "regulada y encerrada debaxo de las reglas y preceptos de la latina", se podía observar la abundancia de vocablos; la conveniencia que éstos tienen con las cosas que significan; las maneras diversas y curiosas de hablar; el suave y buen sonido de la pronunciación; la facilidad para escribirse con los caracteres y letras latinas; el orden y adorno de declinación, y las propiedades del nombre, modos, tiempos y personas del verbo; en fin, en muchas cosas y maneras de hablar, la lengua general se encontraba conforme a la latina y española. La pulidez, abundancia y regularidad, que definían el arte y el artificio de la lengua general, eran consideradas, por Domingo de Santo Tomás, como un "pronostico, que Españoles la auian de poseer" (Domingo de Santo Tomás 1951 [1560]: 10).

$\mathrm{El}$ arte de la lengua general permitía desmentir la noción de una lengua bárbara, es decir "llena de barbarismos y defectos, sin modos, tiempos, ni casos, ni orden, ni regla, ni concierto". Por otra parte, esta pulidez y delicadeza se podía extender también a "la gente que vsa della, no entre barbara, sino con la de mucha policia la podemos contar" (Domingo de Santo Tomás 1951 [1560]: 11). De manera que el arte, que se observaba en la lengua general, era la expresión del artificio de un régimen de concierto y policía. Para fray Domingo de Santo Tomás, la lengua general era la ratio de un régimen político, urbano y cortesano, y el vehículo de la comunicación propio de hombres de razón, de "gente de muy gran policia y orden".

Incluso el arcediano de la Iglesia Metropolitana de Lima, el doctor Fernando de Avendaño, proponía, no sin ciertas dudas, que la lengua quechua y aimara procedían de algunas de las setenta y dos lenguas matrices enseñadas por Dios a los nietos de Noé, o incluso de la propia lengua latina. Para él no se trataba de lenguas inventadas, como aquellas que se pudieron derivar de las setenta y dos lenguas matrices por motivo de guerra, pues "el inca no pudo inuentar de nueuo una lengua tan hermosa, y de tanto artificio [=compostura] como la lengua latina" (Avendaño 1649: 112r). Pero de esta constatación no se deriva, como en fray Domingo de Santo Tomás, una valoración de quienes hablaban la lengua. Más bien debe ubicarse en una estrategia retórica que tendió a remarcar la idolatría de los descendientes de Noé que habrían poblado las Indias y, por extensión, la de los propios indios antes de la llegada de la predicación del Evangelio (González 2014: 209).

\section{Lengua y evangelización}

En la primera mitad del siglo XVI, la iglesia misionera tendió a privilegiar la prédica y el adoctrinamiento en lengua indígena, desentendiéndose de las disposiciones reales que ordenaban la enseñanza en lengua castellana (Cortés 1987: 50). En esto tan solo retomaron una experiencia anteriormente practicada en la evangelización de la población árabe de Granada (Zwartjes 2000: 2) ${ }^{7}$. En Nueva Castilla, se confeccionaron cartillas en lenguas indígenas que contenían los principales principios de la fe, pero no seguían una estructura común en su redacción. Esta experiencia se replicó en la temprana evangelización de las poblaciones indígenas del área andina, pero encontró resistencia en la jerarquía episcopal. A juicio del obispo Jerónimo de Loaysa, esta falta de uniformidad, en los contenidos de las cartillas, 
podía suscitar, entre los indios, el equívoco "que en las cosas de nuestra fe ay mudança o que les enseñavan novedades" ${ }^{\text {. }}$. Por lo que se prohibió la utilización de estas primeras cartillas catequéticas, hasta que fuesen debidamente examinadas, y se aprobó la utilización de una cartilla en lengua latina o en castellano.

Aunque el Primer Concilio Limense (15511552) mantuvo la necesidad de homogeneizar la enseñanza de la doctrina, y que se utilizase la lengua castellana, no obstante estableció la utilización de una cartilla en lengua general quechua por ser la que más comúnmente utilizaban los indios (Vargas 1951 tomo I: 7). Más aún este Concilio dispuso que los indios adultos debieran ser instruidos en su propia lengua, para que entendiesen "lo que en el baptismo reciben y sepan lo que en el catecismo se les pregunta" (Vargas 1951 tomo I: 10). En esta línea fray Domingo de Santo Tomás bosquejó una "Plática para todos los indios" (1560), escrita en quechua, como suplemento a su Gramática o Arte de la Lengua General.

El Segundo Concilio Limense (1567) incorporó una orientación menos ambigua en lo que respecta a la utilización de las lenguas indígenas en la evangelización, disponiendo la obligatoriedad de los sacerdotes en aprender la lengua de los indios. De acuerdo a la constitución conciliar, el aprendizaje de las lenguas indígenas permitiría, a los doctrineros, una prédica "con la que pudieran conmover no solo los oídos de los indios oyentes sino también el ánimo". En esta perspectiva, el dominio de las lenguas indígenas permitiría a los sacerdotes "amonestar de modo suficiente a los pueblos sometidos, para que se les enseñe y para mostrar todas aquellas cosas que por la forma de la piedad cristiana, es necesario demostrar como los sacramentos que deben administrar por oficio [...], que tengan virtud para consagrar de modo competente". Además, el Concilio estableció una serie de sanciones para aquellos doctrineros que se mostrasen negligentes en el aprendizaje de las lenguas indígenas (Vargas 1951; I: 161).

El Tercer Concilio Provincial Limense (15821583) reforzó la evangelización en lenguas indígenas. A partir de las orientaciones del Concilio de Trento, el Tercer Concilio dispuso la utilización de un catecismo, para la enseñanza de los indios, en lengua quechua y aymara. Junto con esto, este Concilio encargó a los obispos la traducción del catecismo a las lenguas predominantes en sus diócesis, siempre que fuesen distintas del quechua y aymara (Vargas tomo I: 323). De este modo, se alentó la instrucción en lengua indígena, prohibiéndose que los indios fuesen compelidos "a aprender en latín las oraciones o cartillas, pues les basta y aún les es muy mejor saberlo y decirlo en su lengua" (Vargas 1951; I: 325). Esta actividad misionera redundó en una gramatización de las lenguas indígenas (Zwartjes 2000), de acuerdo a un modelo gramatical latino, en el caso de las lenguas generales del virreinato peruano ${ }^{9}$. Este proceso de gramatización y de predicación en lengua general, también permitió, como ha señalado Taylor, la propagación del "conocimiento del quechua 'normalizado' en regiones donde, a la llegada de los misioneros en el siglo XVI, no se comprendía la lengua general" (Taylor 2000: 40).

La pastoral en lengua indígena se vio favorecida por una serie de medidas impulsadas por la monarquía, entre estas la creación de cátedras de lenguas indígenas, pero que no encontraron una rápida ejecución. En 1577 se instruyó al virrey Francisco de Toledo que tomase las medidas más convenientes para la instalación de cátedras de las lenguas indígenas ${ }^{10}$. A esta medida siguió una provisión que debía ser observada en la creación de dichas cátedras en la Universidad de los Reyes y en aquellos lugares en que hubiese audiencias, pero se planteaba la noción de una cátedra de lengua general ${ }^{11}$. La misma provisión fue remitida a la Audiencia de los Charcas, expresándose que el conocimiento de la lengua general constituía "el medio principal para poder hazer bien sus oficios", de manera que los "naturales viuiessen en el verdadero conocimiento y religion Christiana, oluidando el error de sus antiguas ydolatrias" ${ }^{12}$. Entre otros aspectos, la provisión establecía que ninguna persona podía ser ordenada sacerdote sin saber la lengua general, y sin la certificación del catedrático que señalase que había cursado al menos un curso entero -es decir, desde el día de San Marcos hasta la cuaresma siguiente. En esta provisión, el conocimiento de la lengua de los indios era considerada como más importante respecto de la suficiencia que hubiese demostrado el ordenante en el conocimiento de los cánones sagrados. En concordancia con esta orientación, se prescribía que en la nominación de curas doctrineros se prefiriera a quienes tuviesen un buen dominio de las lenguas, y obligaba también que los doctrineros que estaban en propiedad de un curato debían, en su oportunidad, cursar y demostrar suficiencia en la lengua general. Incluso se llegó a establecer que en el lapso de un año, a partir de la 
publicación de la provisión en el obispado, todos los curas doctrineros debían ser examinados en el conocimiento de la lengua, de lo contrario los beneficios de los que gozaban se declararían vacantes.

Sólo hacia 1581, en las ciudades de Lima, La Plata y Quito, se planteó la necesidad de establecer "cátedras donde se lea la lengua general de los yndios y que los estudiantes cursen en ellas y no puedan ser ordenados sacerdotes sin saberlo y auer cursado vn curso" 13 . Pero al parecer no hubo una implementación de esta cátedra y tampoco una observación rigurosa respecto de la obligación que los doctrineros tenían de dominar la lengua general. El saliente Virrey Toledo, informaba al rey que era "tan floja la doctrina que a dichos naturales se hacía [...] porque muchos y casi más de los clérigos y frailes que estaban en las doctrinas, no sabían, no entendían la lengua de los indios" (Hanke 1978; I: 130). Esta mirada crítica fue compartida por miembros del Consejo y se expresó en el juicio que muchos clérigos atendían "mas a las inteligencias y granjerias con que poder enriquezer que a saber la lengua de los indios, ni hazer el fruto que conuiene en su conuersion y doctrina" 14 . Por lo que en posteriores instrucciones se volvió a encargar a los virreyes que se observasen las disposiciones reales sobre el dominio que los doctrineros debían tener de la lengua de los indios. Lo que puede explicar que en la Instrucción, dada al virrey Luis de Velasco (1595), se le solicitase que procurara que los clérigos y frailes "que se presentaren para las doctrinas de dichos indios sepan la lengua de aquellos que hubieren de enseñar, por lo mucho que esto importa, pues le servirían de poco los curas que no los pudiesen entender y confesar" (Hanke 1978; III: 15-16).

En la audiencia de Charcas la necesidad de dar cumplimiento a la cátedra de lengua volvió a plantearse una década después de dictada la provisión de 1580. En 1591, el licenciado Juan López de Cepeda, presidente de la audiencia (1580-1602), planteó la necesidad de financiar una cátedra de lengua indígena, que "redunda en bien de las almas de los yndios y provecho de los sacerdotes pretensores de las doctrinas pues sin sauer la lengua de los yndios no pueden tenerlas" 15 . Al parecer se estableció una cátedra de lengua, pero en quechua, pues en la información entregada por un testigo, se indicó que fue en tiempos de don Diego de Portugal, presidente de la audiencia (1610-1627), que se solicitó el establecimiento de una cátedra de lengua aymara en consideración de que se trataba de la lengua general que se hablaba en el arzobispado $^{16}$. Evidentemente que varias circunstancias obstaculizaron no solo la implementación de la cátedra sino que la necesidad que los doctrineros dominasen adecuamente la lengua en la que debían adoctrinar a los indios.

En la misma década en que el virrey Toledo señalaba su preocupación por el escaso conocimiento que tenían los doctrineros de las lenguas indígenas, y se impulsaban cátedras de lenguas y se promovía la evangelización en lenguas generales, los curas del obispado de Charcas representaron ciertas aprensiones a estas medidas. El maestro Domingo de Almeyda, en nombre del clero del obispado de Charcas, dirigió una relación al Rey respecto de varios puntos que atañían al gobierno eclesiástico y político, y sobre los cuales se dictaminaron un cierto número de cédulas. En otros aspectos, en la relación se señalaba la dificultad que había para enseñar e instruir, a los indios, "en las cossas de nuestra santa fee catholica en sus lenguas por no ser comunes llanas e ynteligibles aun para los mismos yndios que los de unas provinçias no entienden a los otros" $"$. Con esto se cuestionaba el valor que las estrategias de evangelización había asignado a las lenguas generales, entre ellas el quechua y el aymara, apuntando indudablemente a las variaciones regionales que en estas se observaba. Agregando, además, que las lenguas naturales carecían de "vocablos nonbres y beruos para significar muchas cosas ymportantes", lo que constituía un escollo más para la adecuada enseñanza y doctrina de los indios, por lo que se señalaba la necesidad que se proveyese y mandase que los indios fuesen "enseñados y obligados a sauer la lengua española". Para evitar cualquier recelo respecto que esta petición protegía los intereses de curas que no dominaban con suficiencia las lenguas indígenas, como era el caso del propio maestro Almeyda, esta medida se solicitaba sin que "los que hubieren de ser curas dexen de sauer y aprender las lenguas dellos sino antes para enseñarlos con mas façilidad [a los indios]", debiéndoseles examinar la correspondiente suficiencia en la lengua. Pero, como se verá más abajo, la aprobación del examen no era prueba suficiente del adecuado dominio de las lenguas en las que debían doctrinar los curas, como lo denunció el doctrinero Bartolomé Álvarez en 1588.

La Relación del clero del obispado de Charcas, planteó cuidadosamente su propuesta de 
castellanización, para evitar que fuera percibida como contraria a las posiciones dominantes en la iglesia virreinal y a las propias disposiciones reales. En junio de 1586, el rey había despachado una real cédula al virrey del Perú Fernando Torres de Portugal, en la que se consideraba que el conocimiento de la lengua española era una "cosa tan neçesaria y ymportante al bien espiritual enseñamiento y conuersion de los dichos yndios y a su policia y mejor modo de uiuir". ${ }^{18}$ Sin embargo, no entregaba ninguna directriz sobre este punto, y dejaba en manos del virrey tomar las medidas que fuesen pertinentes. Los diversos problemas que tuvo que enfrentar el Virrey, y los pocos años en que ocupó el palacio virreinal, no le permitieron, quizás, atender esta materia con suficiencia como para exponer un proyecto en el que se asumiese esta demanda.

En 1588, en carta dirigida al rey, el virrey Fernando de Torres expuso sus consideraciones sobre las lenguas indígenas, como instrumento para la conversión y evangelización de los indígenas, a raíz de una cédula que ordenaba que los curas fuesen examinados en Lima ${ }^{19}$. Aunque el virrey consideraba que el dominio de las lenguas generales, era necesario para que los sacerdotes pudiesen desarrollar sus actividades, y valoraba el establecimiento de una cátedra de lengua general -por cuanto podía aumentar el número, hasta entonces escaso, de sacerdotes que dominasen la lengua-, sin embargo visualizaba algunos inconvenientes. El virrey señalaba que, dada la extensión del distrito, que comprendía el arzobispado, el obispado del Cusco y parte del de Quito, resultaba muy dificultoso para los sacerdotes con experiencia y cierto caudal poder trasladarse, en tan gran distancia y entre ásperos caminos, para ser examinados en los concursos de curatos. Lo que dejaba el camino abierto a "clerigos moços y nuevamente venidos a esta tierra que de otra manera no pueden o no merescen ser ocupados". En opinión del virrey, muy probablemente apoyado en juicio ajeno, había una cierta arbitrariedad en la aprobación del examen, por cuanto el catedrático "les da aprobacion [a aquellos clérigos] quando le parece que saben la lengua o oyendole algun tiempo de manera que queden apto para saberla, exercitandole juntamente con la gramatica que el les enseña porque el hablarla o entenderla no lo hace". Pero también al virrey le preocupaba, que curas propietarios, suficientemente experimentados y de calidades, tuvieran que ser excluidos de sus doctrinas. Porque aunque concurriesen a rendir el examen de lengua, los indios quedarían sin pastor y no habría ningún interesado en subrogar la doctrina, por tiempo tan breve, por los costos que el interino tendría que asumir. Ni tampoco era recomendable que lo asumiese temporalmente el doctrinero vecino, pues no podría atender ambas doctrinas por la extensión de su jurisdicción y población. Por lo que determinó que los examinadores estuviesen en las cabeceras de los obispados, nombrados por el obispo, o en las ciudades comarcanas bajo la vigilancia del corregidor.

Hacia mediados de 1596, en una cédula dirigida a la Audiencia de Charcas, se volvía a discutir la utilización de la lengua indígena y se planteaba cierta duda respecto de la efectividad de las cátedras de lengua. De acuerdo a la cédula, "en la mejor y perfecta lengua de los indios no se puede explicar bien ni con propiedad los misterios de la fe, sino con grandes ábsonos [=disonancias] e imperfecciones", pero también agregaba que "aunque están fundadas cátedras donde sean enseñados los sacerdotes que hubieren de doctrinar a los indios, no es remedio por ser grande la variedad de las lenguas" ${ }^{20}$. Bajo estas dos consideraciones se alentaba a "introducir la [lengua] castellana como más común y capaz". Pero la castellanización de los indígenas no era visualizada como una estrategia compulsiva, sino que debía realizarse voluntariamente. Lo que se reafirma también en la obligatoriedad de que los curatos fuesen proveídos "en personas que sepan muy bien la lengua de los indios que hubieren de enseñar". De este modo, la Cédula tendió a reforzar, sin que fuese su propósito, una política de evangelización en lengua indígena posponiendo el programa de castellanización de los indígenas ${ }^{21}$.

Incluso, como se ha señalado más arriba, esta política encontró fuerte apoyo en las autoridades políticas y eclesiásticas del virreinato, y contó con el apoyo de importantes intelectuales como el jesuita Joseph de Acosta. A pesar de las ambigüedades presentes en la obra de Acosta, y de su negativa a otorgar a las lenguas indígenas una capacidad para traducir los conceptos de la doctrina cristiana, entre estos la posibilidad de localizar una palabra indígena para Dios, sin embargo, consideró, a propósito de las Reglas para el Colegio de los jesuitas (1578), que no convenía "hacerles españoles en todo, porque demás de ser muy difícil y que será ocasión de dejarlo todo, es gran perjuicio para su gobierno y república dellos" (Helm 2002: 153). En esta línea de pensamiento, Acosta abogó por la conservación 
de las costumbres indígenas que no fuesen contra la justicia, de manera de organizarlas jurídicamente a partir de aquéllas. Entre estas costumbres localizaba las lenguas indígenas.

\section{Acosta y Bartolomé Álvarez}

En De Procuranda indorum salute, Acosta sostenía que el dominio de las lenguas indígenas constituía, junto a la integridad de vida y la suficiencia de conocimientos, un aspecto clave para asegurar la salvación de los indios ${ }^{22}$. La palabra de Dios solo podía llegar "a oídos humanos" anunciada "con palabras humanas" (Acosta 1987 [1576]: 47). Su experiencia en "el negocio de la salvación de los indios", le aconsejaba que el conocimiento y dominio de las lenguas indígenas permitiría una rápida penetración del "evangelio de Cristo en el alma de los indios y desplegaría su propia virtualidad, ya que hasta el día de hoy parece que las más de las veces solamente ha tocado en los oídos de los indios sin tocar el fondo del corazón". La prédica en lengua indígena era un vehículo más apropiado para atraer la voluntad y alentar el afecto por el evangelio. Al escuchar la prédica en su propia lengua, los indios "le siguen con toda atención y disfrutan sobremanera de su elocuencia, están embobados del que habla y boquiabiertos y extasiados, con los ojos clavados, están pendientes de sus palabras" (Acosta 1987 [1576]: 51). La comprensión y bondad reinaban, según el optimista Acosta, entre los pueblos que contaban con sacerdotes que hablaban las lenguas indígenas, lo que contrastaba ampliamente en aquellas regiones que contaban con ministros que ignoraban y despreciaban la lengua de los indios.

No todos consideraban que la prédica en lenguas de indios tuviese un valor en sí misma. El doctrinero Bartolomé Álvarez, crítico agudo de los jesuitas y del Tercer Concilio Limense, sostenía que la predicación entre los indios había sido infructuosa, pues no se podía persuadir, por medio de las historias evangélicas, a gente que juzgaba incapaz y en condición de bestia. La estructura retórica de la prédica, la considera un medio dificultoso, dada la exigencia de entendimiento que requería, preguntándose “¿Qué aprovecha [la] retórica de estudiadas palabras en la lengua de los indios, ni ordenadas historias del texto sagrado, pues no creen [=que exista] el Señor?" (Álvarez 1998 [1588]: 315). Corchetes de los editores). La estrategia de Álvarez era más inquisitiva, apoyada en el juicio natural del sacerdote más "que en otras letras", lo que le permitía:

meterse con ellos en las ratoneras sucias de sus entendimientos a sacarles y declararles [=hacerles patentes] sus pensamientos, manifestándoles en lo claro sus malos intentos y obras, declarándoles con palabras de razón natural cómo todo lo que hacen, entienden y quieren son suciedades de pecados torpes (Álvarez 1998 [1588]: 314. Corchetes de los editores).

Al poder de la prédica, y de la virtud esperada de los exempla de sermonarios, se anteponía la necesidad de inquirir meticulosamente en los pensamientos de los indígenas para declarárselo y "afeárselo, por todo el mal que en sí contienen los males que hacen". No bastaba con que el doctrinero se contentase con las imágenes del castigo, expandidas por la pastoral del miedo, sino que "algunas veces es necesario que lo vean, porque lo ven no lo creen" (Álvarez 1998 [1588]: 316) ${ }^{23}$. La única vía posible para saber con certeza la vida de los indios, sus errores y pecados, era trabajar con los indios al punto que los doctrineros "se vuelvan indios para que puedan alcanzar las cosas de los indios, y entender las inteligencias dellos para contrastar todas sus obras", tal como un médico debía enfermarse para poder transmitir salud (Álvarez 1998 [1588]: 317).

Entre otros aspectos, esto requería de un conocimiento agudo de las lenguas de los indios. Sin embargo, Bartolomé Álvarez veía en estas una de las mayores dificultades para la conversión y evangelización de los indígenas, porque a diferencia de las posiciones mantenidas por fray Domingo de Santo Tomás e incluso del jesuita Acosta, consideraba "que a los indios les faltan los vocablos y maneras de hablar más necesario a la confabulación [=explicación] de las cosas de nuestras santa fe católica" (Álvarez 1998 [1588]: 143. Corchetes de los editores). La introducción de vocablos castellanos, que se habían incorporados en el sermonario y catecismo del Tercer Concilio Limense, resultaban inapropiados, porque de estos nuevos vocablos no había un uso anterior que les permitiese "creer lo que por ellos se les significa" (Álvarez 1998 [1588]: 144). Cuestión que le permitía fundamentar el rigor en la persecución de sus malas costumbres como vehículo para desarraigar y quitar los pecados. Además, el antiguo doctrinero 
de Aullagas consideraba que la "inteligencia material" de los indios solo les permitía tener un escaso conocimiento de las "cosas que ven", lo que dificultaba mayormente la comprensión de las "cosas espirituales inteligibles" (Álvarez 1998 [1588]: 148).

A pesar de las críticas, y de las diferencias notorias respecto de estrategia la pastoral para la conversión y evangelización, el doctrinero Álvarez estaba plenamente convencido de la necesidad de utilizar la lengua de los indios pero no de homologar su calidad a la de cristianos viejos. Además, él mostraba fuertes recelos respecto del mecanismo utilizado para aprobar el conocimiento de las lenguas generales, pues consideraba que quienes eran aprobados no sabían más que "los nominativos y las conjugaciones", por lo que ese conocimiento rudimentario colocaba a estos doctrineros en el mismo nivel de entendimiento que los indios a su cargo. En esto no veía otra cosa que un designio divino por cuanto eran tales los pecados de los indios "que por ellos no les quiera dar Dios candelas que los alumbren" (Álvarez 1998 [1588]: 214) ${ }^{24}$.

Acosta también asumió una actitud que él mismo juzgaba rigorista, pues sostuvo que el sacerdote que desconocía la lengua de sus fieles, no podía enseñar ni predicar la fe, ni tampoco administrar debidamente el sacramento de la penitencia. Desestimaba el uso que algunos doctrineros hacían de intérpretes para sus confesiones, pues le quedaba oculta la mitad de estas, no pudiendo dirimir la medicina apropiada a cada uno de los pecados. No obstante, dada la escasez de misioneros, el padre Josep de Acosta veía no sin recelo y solo como una medida transitoria el nombramiento de doctrineros que desconocían la lengua indígena.

Por otra parte, Acosta se mostraba contrario a las opiniones de aquellos sectores que alentaban la castellanización de los indios, como las expuestas por Juan de Matienzo en 1567. El oidor de la Audiencia de Charcas había observado que la enseñanza de la lengua castellana era un instrumento imprescindible para que los indios viviesen en policía civil y cristiana. Por lo que los caciques debían ser obligados, con pena de ser privados de sus cargos, a hablar la lengua castellana con sus indios, como había sucedido en tiempos del Inca. Además, el conocimiento de la lengua castellana, permitiría que los indios "aprendieran mexor la dotrina evanxélica, porque su lengua no tiene vocablos aptos para comprender y entender lo que se les pretende enseñar" (Matienzo 1967: 21[1567]). La posición de Matienzo era contraria a la que adoptó la iglesia virreinal en los concilios de 1567 y 1583 respecto de evangelizar en lengua general. Esta última fue la posición que mantuvo el Virrey Toledo, aunque en sus ordenanzas establecía "que todos hablen la lengua general del Ynga [el quechua] y aprendan la española y usen de ella, de manera que en las dichas lenguas se les pueda enseñar la doctrina cristiana, y ellos la puedan aprender y mejor comunicar con los españoles" 25 . No obstante, con anterioridad el virrey Toledo había señalado al quechua, puquina y aymara como las lenguas "que generalmente se hablan por los indios de estos reinos, y provincias del Perú", por lo que había nombrado a Gonzalo de Holguín como intérprete general de los indios ${ }^{26}$.

Los proyectos de castellanización de las poblaciones indígenas fueron, para Acosta, leyes propias a una república platónica en la que se "fabrican leyes con palabras vacías -cosa fácil- que al aplicarlas quedan en pura fábula" (Acosta 1987: 63[1576]). En esto él ponía como ejemplo a los propios españoles quienes, "estando en patria extraña", no habían podido olvidar su lengua y aprender la de los indios, habida cuenta de su ingenio y de la necesidad imperiosa que tenían en comunicarse en una patria extranjera. Además, Acosta asumía que era imposible que se extendiese la castellanización en un población en que el español se oía "raras veces y muy a disgusto", resultando incluso impracticable que se pudiese controlar el uso de la lengua en sus casas cuando trataban "de sus asuntos en su lengua materna" (Acosta 1987: 65 [1576]). Tampoco se mostró partidario de la utilización de lenguas generales, cuyo uso y entendimiento restringió a los indios principales, pues mujeres, niños y atunrunas, "raza de hombres sin cultura, [que] apenas saben algunas palabras [de la lengua general]"27.

No debe verse en estas posiciones de Acosta una defensa per se de las lenguas indígenas, sino que la consideración de estas como un instrumento adecuado para la temprana evangelización de los indios, de manera de impedir los graves inconvenientes que surgían de la "tan espesa selva de idiomas" que habían en las Indias. Las lenguas indígenas se ponían, pues a disposición de un proyecto de evangelización, pero no se descartaba la castellanización posterior de las poblaciones indígenas.

De manera general, se puede establecer que en las últimas dos décadas del siglo XVI, primó una estrategia de evangelización en lenguas generales, que minimizó la política de castellanización de las 
poblaciones indígenas. Lo que no debe descuidar otros procesos como la expansión del quechua y del aymara, en detrimento de otras lenguas, y el propio uso del castellano en un segmento no despreciable de los grupos indígenas tempranamente mestizados. En todo caso, la utilización de las lenguas generales para el adoctrinamiento de los indios, siguió siendo considerado como un aspecto central de la pastoral como lo señala la documentación analizada por Bouysse-Casagne (1987).

\section{Siglo XVII}

Hacia 1604, en el hasta entonces obispado de La Plata, se establecieron las lenguas en las que debían ser instruidos los curas doctrineros para la predicación del evangelio y de la doctrina cristiana $\left(\right.$ Espinoza 1980) ${ }^{28}$. Aunque el documento consignaba al aymara como lengua general del obispado, sin embargo en varias de las ciento cuarenta doctrinas se hablaba, además, quechua, puquina y, en menor medida, uroquilla (ver Tabla 1). Pero varias de estas lenguas se hablaban en un mismo curato, lo que colocaba cierta dificultad en el nombramiento del cura doctrinero. Para resolver este inconveniente, en el obispado se impuso un procedimiento general que dio predominancia al adoctrinamiento en aymara en las doctrinas de Potosí, Chucuito, Chuquiavo, Pacajes, Carangas, Charcas y Quillacas, aun cuando se hablara también quechua, puquina o uruquilla. Pero se mantuvo la prédica en quechua en aquellas doctrinas en que los feligreses eran quechuahablantes como en los curatos de San Lázaro y San Sebastián, en la ciudad de La Plata, en las doctrinas de Guata y Sicha, además, del curato de piezas de esclavos de Potosí. En las doctrinas de Omasuyo el doctrinero debía saber aymara o puquina, mientras que para las doctrinas de Capachica y Coata se debía conocer el puquina.

El esfuerzo eclesiástico por delimitar el adoctrinamiento en lenguas indígenas encontró una primera dificultad en la preparación de los propios doctrineros. Al promediar la primera década de 1600 , el conocimiento que tenían los curas doctrineros de las lenguas indígenas no había experimentado grandes cambios respecto de lo que señalaban las autoridades virreinales en el siglo anterior. En la provincia de los Charcas, el arzobispo Alonso de Peralta reconocía que muchos de los naturales del arzobispado carecían de la doctrina necesaria para

Tabla 1. Lenguas y curatos del obispado de La Plata (1604).

\section{Lengua}

Aymara

Quechua

Puquina

Aymara-quechua

Aymara-puquina

Aymara-quechua-puquina

Aymara-uroquilla

\begin{abstract}
Curatos
San Bernardo (Potosí), San Francisco (Potosí), San Cristóbal de la Merced, La Concepción, San Martín (Potosí), Tarapaya, Santiago de Porco, San Bartolomé de Porco, Atacama, Tomahaui, Las Salinas, Condocondo, Chayllapata, Hatun Quillaca, Andamarca y Orinoca, Colquemarca, Chuquicota, Sabaya, Guachacalla, Curaguara de Chuquicota, Guayllamarca, Totora, Turco, Xulloma, Callapa, Caquingora, Calacoto, Caquiauiri, Santiaga de Machaca, Machaca la Grande y Machaca la Chica, Guaqui, Zepita, Yonguyo, Pomata, Hilaui, Juli, Acora, Chuquito, Icho y Puno, Huyuni, Sonco, Challana y Chacapa, Llaxa, Viacha, Tiguanaco, Palca y Huyune, Chapes, Zapaqui, Calamarca, Ayohayo, Sicasica, Yacu y Luriguay, Niquicuui, Capinota y Cauari, Suri, Mohoza, Sipisipi, Santiago del Paso, Tiri Quipaya, vicario de Cochabamba, Nuestra Señora de Belén, Macha, Copoata, Chayanta, Sacaca, Clipca, Yungas de Pocona, Copavilqui, Vitora, Poroma, Santiago de Moscari, Calapiquiña, San Marcos, Popo, Calcha, Talma, Toropalca y Caysa, Talauera de Puna, Chaqui, Tacobamba, Potobamba, Cotagaita, Moromoro, San Lucas de Paacollo, Capinota, Charamoco, Tapacari.

Curato de piezas (Potosí), San Lázaro (La Plata), San Sebastián (La Plata), Guata, Sicha

Coata y Capachica

Nuestra Sra. De los Carangas (Potosí), San Benito (Potosí), San Juan (Potosí), Santiago (Potosí), San Pedro (Potosí), Porco, Vraimir y Coroma, Copacabana, Chuquiavo, Caracoto, Pitantora, Santiago de Curi, Valle de Mojotoro, Atumyampara, Tomina, Tarija, Pilcomayo, Sopachuy, Tinquipaya, Tarabuco, Presto, Pacha, Horoncota, Arauati, Pocona, Mizqui,

San Francisco de La Puna, Guacane, Vilque, Moho, Guaycho, Achacache, Guarina.

San Agustín (Potosí), San Sebastián (Potosí), Oxalca y Mocomoco, Charazani, Camata y Carixana, Chumas y Ambana, Ancoraimes y Carabuco, Yotala, Quilaquila.

Lipez, Aullagas, Huroquillas de Zepita, Paria.
\end{abstract}


la salvación de sus almas, por lo que estaban "desnudos no solo de los bienes temporales sino de los spirituales" 29 . Una situación que había denunciado, a inicios de la década de 1590, el chantre de la Catedral de Lima, comisionado en la diócesis de La Plata, constatando la nula sujeción que tenían españoles e indios a las cosas espirituales (Querejazu 1995: 88). Lo propio señaló, en 1597, el obispo Alonso Ramírez de Vergara (1596-1602) cuando informó de la ruina y menoscabo que experimentaban en la diócesis las cosas eclesiásticas y espirituales. Entre otras situaciones, el obispo denunció la poca o nula capacidad que tenían algunas personas eclesiásticas para el desempeño de sus oficios ${ }^{30}$. En 1613, el arzobispo Alonso de Peralta volvía a insistir en la continuidad de estas conductas, enfatizando que se arrastraba desde los primeros tiempos de la evangelización, cuando las circunstancias obligaron a suplir la falta de doctrineros con "clerigos que apenas sabian leer Romançe y totalmente ignorantes en la doctrina christiana", por lo que de ellos no podría esperarse ninguna buena doctrina y ejemplo para el pueblo. Había la convicción que estos doctrineros ignorantes, solo interesados en acrecentar sus ingresos, habían dado a sus feligreses indios "un tasito permiso para que preservasen en sus idolatrías y borracheras y acudiesen a sus fiestas, pues en ellas mostraban sino de traer a la memoria las cosas pasadas, permaneciendo en sus antiguos viçios y torpezas que avn dia de oy ay mucho desto" 31 . Además, el arzobispo Peralta denunciaba que los curas habían tenido tal negligencia en el cuidado de sus ovejas, particularmente en su enseñanza y adoctrinamiento, "que las an hallado incapaces aun en el articulo de la muerte para darles el viatico".

Casi una década más tarde, el arzobispo fray Jerónimo Méndez de Tiedra, informaba al Rey que los clérigos que pasaban a su diócesis eran escandalosos, ignorantes, mal nacidos y carentes de patrimonio y beneficios suficientes para ordenarse, por lo que solo les interesaba granjearse la plata. Agregaba que "no sirben cosa alguna como ydiotas e ignorantes de la lengua de los yndios su ocupacion es allegar misas con mucho mal exemplo y peligro de su alma que vn dia vno de ellos estando en peligro de muerte declaro deber mill missas" 32 . Estas críticas las dirigía tras haber concluido, en 1620, el primer sínodo del arzobispado de La Plata. En lo concerniente a la predicación en lenguas indígenas, el Sínodo dispuso que los curas de indios enseñasen la doctrina cristiana "por sus personas en la lengua de los mismos indios todos los dichos días de domingos y fiestas del año" (Méndez de Tiedra 2002: 11 [1619-1620]). Además, el sínodo estableció que en aquellos lugares que se pudiera realizar, se juntasen los indios para la doctrina los días miércoles y viernes, mientras que los menores de doce años debían ser compelidos a asistir a la doctrina todos los días mañana y tarde. Siguiendo las disposiciones del Tercer Concilio Limense, se ordenaba también que los curas de indios no utilizasen, en las prédicas, intérpretes en las lenguas quechua y aymara.

En la misma década en que terminaba el Sínodo Platense, el obispo de Arequipa defendía, en una carta enviada al Rey, la necesidad que los indios aprendiesen la lengua castellana ${ }^{33}$. Esta posición se apoyaba en la representación de los indios como "salvages, e inabiles", o como "barbaros inconstantes i fáciles", a partir de la cual se fundamentaba la subordinación colonial, y se sostenía la pérdida de libertades y fueros. Entre estos estaba el uso de las lenguas nativas, por lo que se proponía que los indios aprendiesen "la lengua de los que los goviernan en lo temporal i espiritual" 34 . En la perspectiva del obispo, el dominio del castellano era un instrumento tanto para la conversión de los indios como para su incorporación a "costumbres humanas i políticas, sacándolos de la fiera i barbara brutalidad en que los hallamos y mantenerlos en paz i justicia”. Pero también esta propuesta buscaba promover, a los curatos, a sacerdotes que no dominaban las lenguas generales, y que probablemente formaban parte de la clientela del obispo (Castro e Hidalgo 2014).

La propuesta del obispo de Arequipa estaba muy alejada de las orientaciones de la iglesia virreinal en lo referido al uso de lenguas generales en la actividad pastoral. En la visita practicada por el obispo de La Paz, Feliciano de Vega, iniciada en 1634, se constató que algunas doctrinas estaban encomendadas a curas que no sabían la lengua general, en la que debían adoctrinar a los indios, por lo que determinó colocar coadjutores en dichas doctrinas, sin el consentimiento del Real Patronazgo. El obispo fundamentaba esta última decisión, en la gravedad que revestía la presencia de curas doctrineros que desconocían las lenguas generales. Por lo que dispuso que los curas doctrineros rindiesen un examen de lengua en un plazo de seis meses, tras el cual, y no constatándose su dominio de la lengua general, debía declararse por vacantes las mencionadas doctrinas. Además, determinó que 
para "preuenir este daño para lo de adelante y que aya mas ministros en quien hazer eleccion", colocar "vna leccion de lengua a mi costa en el colegio seminario, y la he encargado al Maestro Esteuan Guerrero presbytero, que la lee con cuiado, y con esto espero en Nuestro Señor cesaran los grandes inconuenientes que ha auido en lo pasado" 35 .

Estas medidas del obispo, coherentes con la política de evangelización en lenguas generales dominante en el arzobispado, debieron hacer frente a las políticas de castellanización que promovía la alta burocracia imperial. En la Instrucción al conde de Chichón (1628), se encomendaba que los indios fuesen enseñados y adoctrinados en lengua castellana para que viviesen en policía y para "que desde niños aprendiesen la lengua castellana, también porque en la suya se dice que les enseñan sus mayores los errores de sus idolatrías, hechicerías y supersticiones, que estorban mucho en su cristiandad" (Hanke 1978; III: 31). En esta misma perspectiva, se sitúo la cédula de 2 de marzo de 1634, que se envío a los arzobispos y obispos de la Indias, en la que se expresaba la necesidad de enseñar a los indios la lengua española "para poder ser enseñados con perfeçion en nuestra Santa fee católica por personas de toda satisfacion y virtuosas de que hasta se a necesitado por no sauer la lengua de los indios y por esta causa ser necesario encargar su dotrina a otros que la sauen de menos satisfaçion" 36 . La cédula expresaba una crítica a la predicación por medio de intérpretes, especialmente en el caso de las pláticas y sermones de los prelados, porque no era "posible llegue la dotrina a sus coraçones con la pureça y feruor que si la entendieran". El aprendizaje de la lengua española se juzgaba como provechoso para la salvación de las almas y de utilidad para el gobierno y modo de vivir de los indios. Por otra parte, se consideraba que el proyecto no tenía dificultad para su implementación por cuanto en tiempos del inca se "obligo a que todos supiesen su lengua quichua, y la aprehendieron" 37 .

En medio de la visita pastoral, hacia 1635, y estando en los confines de la doctrina de Larecaja, el obispo Feliciano de Vega recibió la cédula de 1634. El obispo no solo sostuvo haber dado cumplimiento a esta disposición real, sino que compartió que la castellanización se debía realizar:

para el bien desta gente miserable, y para que pueda auer mas ministros en adelante, y en especial en estas Prouincias donde por hablarse la lengua aymara, y la puquina que son difíciles, y en particular esta vltima, que consiste lo mas della en la guturación, ay gran trabajo en hallar quien los entienda para las confesiones y predicación del santo evangelio ${ }^{38}$.

A juicio del obispo Feliciano de Vega, esta disposición, presente en el capítulo sesenta de la instrucción general que se daba a los virreyes, no se había ejecutado hasta el presente. En un cambio repentino de perspectiva también aseguraba, siguiendo el tenor del mencionado capítulo, que la castellanización era el único medio "para que se escusen los errores de las idolatrias, echicerias y supersticiones" 39 . ¿Habrá correspondido este cambio de perspectiva a los conflictos que mantuvo, durante la visita pastoral, con los misioneros jesuitas de Juli que se negaron a que el obispo visitara sus parroquias? ¿No eran ellos acaso los más entusiastas partidarios de la política de evangelización en lenguas indígenas? Tal vez esta situación pudo afectar la perspectiva del obispo, pero tampoco puede desconocerse que, para un obispo recientemente llegado, había también la necesidad de articular un control sobre las parroquias a su cargo, del que, en todo caso, pretendía sustraerse el clero regular.

En cualquier caso, a pesar de las disposiciones reales, la política de evangelización en lengua indígena siguió manteniendo el apoyo en el arzobispado. El rector del Colegio de la Compañía, ante la eliminación que se proponía de la cátedra de lengua aymara y la pérdida de la limosna que la mantenía, solicitó se hiciese información de oficio para establecer la utilidad de la cátedra y la enseñanza de la lengua aymara que se leía en su colegio y la necesidad de financiarla. A su juicio, la lectura y enseñanza del aymara era "mui neçesaria y preçissa por ser el ydioma en que generalmente comunican y deuen ser doctrinados todos los yndios deste Arzobispado, y que el cura que no la saue no puede cumplir con su obligaçion ni descargar la conçiençia de Vuestra Magestad" 40 . El padre Joan Cruz Navarro, racionero de la iglesia catedral, sostuvo que hacía más de treinta años que en el Colegio de la Compañía "se a leydo y lee la catedra de la lengua aymara por vn religiosso de la dicha compañía con toda puntualidad y por lo que a entendido y viso saue que la dicha cateda y enseñança" era "comveniente y esencial por ser la lengua aymara la natiua de los yndios de todo este arzobispado" ${ }^{41}$. Sin ese conocimiento de 
la lengua, aseguraba el racionero, no era posible que se acudiese "al bien espiritual de los yndios", particularmente en la administración de los santos sacramentos, por lo que sería perjudicial que no se siguiera manteniendo la cátedra de lengua aymara. Los demás testigos, presentados por el rector del colegio jesuita, sostuvieron la necesidad que tenía el cura doctrinero de saber la lengua indígena para un adecuado cumplimiento de sus obligaciones pastorales.

Por las indicaciones documentales, se puede señalar que la política de castellanización no prosperó y que se continuó exigiendo el dominio de la lengua general para postular en el concurso de curatos. De manera que, a fines de la primera mitad del siglo XVII, la enseñanza de las lenguas generales seguía siendo considerada una de las prioridades en la formación de los sacerdotes que se presentaban en dichos concursos. Aunque hubo voces discordantes con esta posición, como las del entonces racionero de La Plata Antonio de Herrera, quien se mostró partidario de la castellanización de los indígenas para que éstos pudiesen contar con doctrineros calificados que pudiesen "extirpar sus ritos e idolatrías" $"$. A juicio del racionero, en otras áreas del virreinato se observaba una cierta correspondencia entre la extensión del uso del castellano y la inexistencia de idolatrías entre los indígenas. Esta situación no se observaba en Charcas. Por lo que el racionero Antonio de Herrera abogaba por el adoctrinamiento en castellano; además, confiaba en que esto permitiría contar con un mayor número de clérigos doctos y santos que pudiesen asumir el oficio de cura doctrinero. No obstante los deseos del racionero, en la arquidiócesis siguió primando la necesidad que los doctrineros enseñasen en lenguas generales. Hacia 1648, el arzobispo de La Plata señalaba que se había dispuesto que en cada iglesia hubiese:

"persona, que leyesse la lengua a los sacerdotes, para que instruidos en ella pudiessen administrar los sacramentos en los lugares, y partes donde fuessen presentados en el officio de curas y que los Prelados antes de la nominaçion del dicho offiçio, viessen la sufficiençia, que podía constar por aprobaçion del maestro de la lengua" ${ }^{43}$.

Entre los miembros del cabildo eclesiástico de La Plata, que ya no contaba con la presencia del fallecido canónigo Herrera, se mantuvo la opinión que los postulantes al concurso de curatos del arzobispado debían dominar las lenguas generales predominantes en las doctrinas que debían servir los doctrineros. No obstante, en algunos curatos coexistían, junto a la general, lenguas nativas como era el caso de Yotala y de Atacama. En el caso de la primera, se hablaba la yamparaez y el quichua; por su parte, en Atacama, de acuerdo a Diego Fernández Triviño, "se hablan dos idiomas, vno, en particular atacama y el general quichua" 44 . En estos casos, los miembros del Cabildo fueron de opinión que el postulante que fuese designado debía aprender, en el lapsus de un año, la lengua nativa del beneficio.

Hacia la década de 1660 , la publicación del Itinerario de Párrocos de Indios (1668) significó un fuerte apoyo para los partidarios de la evangelización en lenguas indígenas. Apoyado en diversas autoridades y disposiciones, generadas tanto en América como en la Península, Alonso de la Peña, obispo de Quito, dedicó algunas secciones del primer libro a defender el necesario conocimiento de la lengua indígena que debía tener el cura doctrinero y a establecer cómo esta falta se oponía al derecho natural y divino. Sentenciaba que no solo permanecía en pecado mortal el sacerdote que hubiese obtenido un curato sin saber la lengua de sus feligreses, sino que también era "inepto para ejercer su oficio, è irregular para admitir Beneficio", por cuanto el oficio de doctrinero consistía en "enseñar predicando la palabra de Dios". Aunque fuese un hombre docto y sabio, todo esto le era "sin provecho si le falta la lengua, pues sin ella está inepto para predicar, y confesar". No hablar la lengua era igual que carecer de esta, particularmente tratándose de un ministerium verbi en el que se requería "predicar, confesar y enseñar los Mysterios de la Fé Catholica" (Peña 1771: 22 [1660]).

En las décadas siguientes, el conocimiento de las lenguas generales siguió considerándose un requisito indispensable en la formación de los sacerdotes. Precisamente, hacia la década de 1680, el procurador de la Compañía de Jesús señalaba que en su colegio:

ha muchos años que se lee en el la Cathedra de Lengua Aymará, que es la general para los Yndios de esta Provincia de los Charcas, y que su enseñanza á aiudado en este Arzobispado muchos curas que la 
saben y entienden y administran en ella los Santos sacramentos á sus feligreses ${ }^{45}$.

Esta relación estuvo motivada por el intento de suprimir el pago, promovido por la Caja Real de Potosí, a la cátedra en lengua aymara regentada por los jesuitas. En esta enseñanza, el procurador reconocía una utilidad y provecho tanto para los curas doctrineros como para los indios. A través de la lengua de sus feligreses, el doctrinero podía realizar una adecuada enseñanza de la doctrina y los misterios de la fe a la feligresía de su curato. Lo que redundaba en provecho de la salud espiritual de los indios, pues podían contar con médicos y jueces espirituales que entendían sus confesiones. Por el contrario, el desconocimiento de la lengua indígena solo provocaba dificultades en la administración de los sacramentos, en la predicación y en la enseñanza de la fe. Lo que indudablemente también afectaba el cumplimiento de las obligaciones propias del ministerio pastoral.

No obstante, la política de evangelización en lengua indígena experimentó algunos contratiempos a mitad de la década de 1680. En 1685, el Rey ordenó que se dispusiesen escuelas para la enseñanza del castellano de acuerdo a lo estipulado en la Recopilación de Leyes de Indias ${ }^{46}$. Retomando orientaciones de fines del siglo XVI, se volvía a insistir que aunque se reputasen como perfectas, las lenguas indígenas no podían explicar con suficiencia los misterios de la fe, más aún las traducciones arriesgaban disonancias e imperfecciones que representaban mayores peligros para poblaciones recientemente conversas. En este contexto, el establecimiento de cátedras para la enseñanza de las lenguas generales también se mostraba insuficiente, pues la variedad de lenguas imposibilitaba que los futuros doctrineros adquiriesen un conocimiento adecuado de estas. Pero la política de castellanización, que promovía esta disposición real, no descansaba solo en consideraciones respecto del instrumento lingüístico más apropiado para el adoctrinamiento de las poblaciones indígenas. Esta cédula recogía las observaciones del virrey Duque de la Palata, quien, en cartas de 1682 y 1683, había señalado que los indios del virreinato conservaban "su lengua yndia como si estubieran en el imperio del Ynga [...] de que resultaua en lo politico y espiritual el mayor impedimento para la crianza de esos naturales" 47 . Por lo que resultaba imperioso que se introdujese la lengua castellana por la utilidad que revestía para el servicio de Dios, la salvación de las almas y la conveniencia para el gobierno político. La posición del virrey era compartida por algunos contemporáneos preocupados por el estado eclesiástico en Perú y Nueva España. Gabriel Fernández y Villalobos señalaba que muchos doctrineros no conocían la lengua de las doctrinas en las que debían desempeñarse, lo que se consideraba que era "una de las mayores ruinas que padezen los yndios para no ser buenos católicos, porque en vano se trata del culto divino, estirpaçión de ydolatrías y de política humana" (1990: 553 [1683]). Pero este arbitrista se mostraba partidario que a los indios desde niños se les enseñara el castellano, prohibiéndoles hablar otra lengua, de manera que en un período de veinte años "vendrán a ser españoles; y con la lengua se les pegaran nuestras costumbres y se olvidarán de sus ritos y ydolatrías" (1990: 555 [1683]).

Esta tentativa de colocar la lengua al servicio de la religión y de la política, se concretó en un proyecto de escuela castellanizante. De acuerdo a la cédula de 1685 , en cada uno de los pueblos de indios debía instalarse escuelas, a cargo de un preceptor que debía enseñar la lengua castellana bajo la vigilancia del cura doctrinero. La función de preceptor podía ser asumida por los sacristanes o por algún indio capacitado, a quienes, en cualquier caso, debía librárseles de tasas, tributos, cargas y obligaciones. Para que esto fuese efectivo se determinó, en consonancia con las disposiciones de la Recopilación, que el dominio de la lengua castellana era obligatorio para ejercer los cargos de cacique gobernador, segunda persona, alcalde, o de cualquier otra ocupación, con la obligación añadida de enseñarla a los propios hijos.

A inicios de la década de 1690, una nueva disposición real volvió a plantear, para las provincias del Perú y Nueva España, la necesidad de establecer escuelas y maestros que enseñasen la lengua castellana a los indios ${ }^{48}$. Esta disposición complementó y precisó algunos aspectos del proyecto de escuela definido en la cédula de 1685. Para las ciudades y pueblos de indios grandes, se planteó la necesidad de disponer de dos escuelas, en las que se enseñase a los niños y a las niñas respectivamente. En el caso de pueblos de indios de menor proporción, se dispuso que niños y niñas asistiesen a una sola escuela pero con separación entre éstos. No obstante, las niñas solo podrían asistir a estas escuelas hasta la edad de diez años, por lo que se prohibía que asistiesen a la escuela una vez cumplida esta edad. Nuevamente 
se establecía, para inducir y obligar el aprendizaje del castellano, que éste era obligatorio para obtener y ejercer cualquier oficio en la república de indios. No obstante, dado que esto afectaba a quienes ejercían cargos en los pueblos de indios, lo que provocaba evidente perjuicio, se estableció un plazo de cuatro años para que dichos indios aprendiesen la lengua castellana. Al término de este plazo, los indios que no hubiesen logrado el aprendizaje de la lengua castellana quedarían excluidos e inhabilitados para ejercer cualquier cargo u oficio.

Se desconoce el impacto que tuvo esta cédula en el arzobispado de Charcas. La única indicación disponible que se tiene hasta ahora, proviene de una carta del obispo de la Paz Bernardo Carrasco y Saavedra (1696-1697), fechada el 8 de junio de 1696, en la que informaba al rey haber recibido la cédula de 1691. De acuerdo a la misiva del obispo, la disposición contenida en la cédula ya había sido ejecutada, por cuanto en los principales lugares del obispado se había fundado escuelas para la enseñanza de los indios. Aunque reconocía que en algunos lugares no se había establecido escuelas, "por la cortedad de la población", sin embargo, aseguraba que pondría "en adelante el fomento posible de mi parte" ${ }^{49}$. El obispo ordenó que los curas doctrineros enseñasen, en lengua castellana, la doctrina cristiana y los misterios de la fe.

\section{Siglo XVIII}

Las visitas pastorales de la primera década del siglo XVIII, y las relaciones de méritos de los curas doctrineros, permiten avanzar, en una primera aproximación, que el uso de lengua general se encontraba expandido en el adoctrinamiento de los indígenas en el arzobispado de Charcas. En algunas visitas pastorales, los obispos contaron con el apoyo de sacerdotes que conocían las lenguas indígenas para cumplir con las tareas pastorales. En 1725, tras trece años sin que se hubiese realizado una visita a la diócesis de La Paz, y tras ser afectada su población por una epidemia y hambruna, el obispo Alejandro Fernández Rojas y Acevedo (1724-1730) llevó en su comitiva al jesuita Damián de la Verdeja por su conocimiento del aymara y del quechua para que en esas lenguas predicase la misión y explicara el sacramento de la confirmación. El obispo juzgaba que, sin ese conocimiento de las lenguas de sus feligreses, no se hubiese "sembrado el evangelico grano entre las incultas espinas de tanta barbaridad" 50 .

No obstante, una temprana voz de discordancia surgió, unos años más tarde, con el recientemente nombrado obispo de La Paz Agustín Rodríguez Delgado (1732-1743). En el informe de su llegada a la ciudad de La Paz, escrita en enero de 1733, había señalado la urgencia de poner "remedio a una grauissima necesidad", el desconocimiento de la lengua castellana, por parte de los indios, que dificultaba la comunicación entre el pastor y sus feligreses ${ }^{51}$. A juicio del obispo, "el que los indios no hablen la lengua castellana, y se les prohíba la suya, ynduze mui malas consequenzias”, 1) por cuanto entorpecía la actividad pastoral, viéndose obligado el prelado a explicarse por señas sin siquiera lograrse hacerse entender por esta vía; 2) dificultaba también el que la visita eclesiástica pudiese desarrollarse "con todas sus prudentes y xptianas zircunstanzias"; 3) sin dejar de mencionar, el estorbo para el trabajo de adoctrinamiento de los curas quienes, aunque supusiesen la lengua, sin embargo no podían ser capaces de manejarse en ésta con la misma propiedad que lo hacían los indios -lo que se evidenciaba particularmente en la implementación de una adecuada confesión, pues los curas se veían "expuestos a muchos engaños", en tanto muchas de las frases, en lengua natural, se prestaban a equívocos en la traducción, "que suenan a un mismo tiempo a virtud, y a vizio";52 4) el obispo consideraba, además, que, dada la dificultad que había en el aprendizaje de la lengua indígena, los curas quedaban a merced de las traducciones de "muchos sujetos por naturaleza yndignos como son yndios y mestizos, de los que ya he encontrado muchos". ${ }^{53}$ Por último, el obispo de La Paz volvía a plantear la inconveniencia de mantener la lengua indígena, que juzgaba como instrumento "para sus falzas oraciones y ydolatrias", y la necesidad de que los indios hablasen castellano por estar "mas conforme a nuestra sagrada religión".

A partir de estas consideraciones, el obispo Fernández Rojas planteó el proyecto de que los curas doctrineros se dedicasen a enseñar, a los niños, la lengua castellana e instruir en ésta a los adultos. Aunque estaba deseoso que esta medida fuese refrendada por la Corona, sin embargo era consciente que las disposiciones reales habían privilegiado la utilización de las lenguas generales. De ahí que, en su respuesta, el fiscal del Consejo haya insistido en la novedad de la propuesta del 
obispo, pues ningún otro prelado de las Indias había "hecho una representación semexante". Más aún si se trataba de una proposición contraria a las disposiciones de la Recopilación de Leyes de Indias, a cuya observación debía someterse el obispo. Para el fiscal, la polémica propuesta, que buscaba que los curas doctrineros no fuesen examinados en la lengua nativa, no tenía otro propósito que "poder libremente presentar en los curatos, y doctrinas a sus familiares, que en otra providencia no pudiera tener efectos por no estar instruidos en el idioma de los indios" $" 54$.

En el informe de su visita, escrita en septiembre de 1733, el obispo Fernández volvió a insistir en estos aspectos. Señalaba que la falta de conocimiento de las lenguas indígenas, lo había afligido por "el excesibo dolor de no poder entender lo que tanto pobre me deseaba explicar, ni quedarme arvitrio para sentarme en una silla a explicarles un punto de Doctrina" 55 . Por lo que insistía en proponer que se mantuviese la cédula que mandaba que los indios hablasen la lengua castellana. A los antecedentes que había señalado en sus informes anteriores, agregaba un aspecto que había deslizado en su primera misiva al rey. No se trataba tan solo que el obispo no pudiese administrar adecuadamente el sacramento de la confirmación, sino que, premunido de su experiencia, señalaba otro tropiezo, pero que esta vez radicaba en los curas doctrineros. En su perspectiva, los curas del país eran los más defectuosos, quienes por lo demás lograban los curatos por su dominio de las lenguas indígenas, lo que dificultaba que un cura español accediese a esos curatos, por la imposibilidad de dedicarse a aprender la lengua. Matizando sus anteriores juicios, que se contradecían con su propia observación, el obispo afirmaba que muchos indios sabían la lengua castellana "y nos entienden aunque lo disimulan" (4r). A esto agregaba, que en el obispado se hablaban cuatro lenguas que hacía muy dificultoso encontrar ni "sujetos tan unibersalmente notisiosos, ni jueces examinadores que pudiesen examinar a cada uno en su territorio". Lo que apoyaba en "los quatro Padres de la Compañia curas de las parrochias de Julli", de mayor inteligencia en las lenguas del Obispado, quienes le habrían señalado que el predominio de la lengua de los indios atraía inevitables y graves daños espirituales, por cuanto ellos mismos temían que no tuviesen doctrineros adecuados en sus provincias. Cuestión que el obispo extendía a los curatos concursados por clérigos seculares.

No obstante, hacia 1750 , el visitador franciscano de la provincia de Charcas denunciaba que los curas doctrineros no administraban debidamente el pasto espiritual a los indios por no saber la lengua, además de la práctica de diversos excesos que redundaban en la destrucción y opresión de los indígenas ${ }^{56}$. Una opinión similar mantenía, en ese mismo período, el obispo de La Paz Matías Ibáñez de Segovia (1749-1751), quien incluso llegó a solicitar que el Colegio Seminario se entregase a la Compañía de Jesús, para formar debidamente a los futuros párrocos. Con esto se esperaba contener dos graves inconvenientes que afectaba la provisión de curatos: "el primero, que se confiera los beneficios a los estraños, por no hallarse, la idoneidad necesaria, en los patricios; y el segundo consiguiente y mucho mas pernicioso que se provean los curatos de los yndios, en sujetos, que no entiendan su idioma natural, con la esperanza las mas veses vana que lo aprehendan, por ser tan difícil, la lengua aymara" ${ }^{57}$. La falta de sacerdotes idóneos para la enseñanza en el Colegio Seminario de La Paz, subsistió porque estos encontraban más atractivo ser promovidos a prebendas eclesiásticas o a algún curato de los diocesis que continuar en el mencionado seminario. Además, se señalaba que muchos "jovenes hábiles, y bien nacidos", no podían aplicarse a estos estudios porque sus padres carecían de las rentas necesarias para financiar sus estudios. Lo que provocaba el indudable perjuicio que las doctrinas siguiesen siendo otorgadas a "forasteros que ignoran el idioma de los indios, y carecerse de sujetos capaces para los demas ministerios eclesiasticos" 58 .

\section{Lengua castellana y civilidad de las poblaciones indígenas en el ciclo borbónico}

Hacia la década de 1770, el cura Juan Josef del Hoyo señalaba que para la instrucción de los indios y la eliminación de las falsas ideas no era suficiente la doctrina de los párrocos. La falta de luces y la incultura hacían poco propicio que fructificase la palabra, por lo que era necesario desmontar y disponer el terreno. La escuela resultaba ser el medio más apropiado para que "los niños de vno, y otro sexo de estos Naturales sean enseñados, á leer, y escribir [....] y que ellos sean obligados, á embiar a sus hijos é hijas a que 
aprehendan" (Hoyo 1917: 177 [1772]. De acuerdo los preceptos pedagógicos de la época, Juan Josef del Hoyo asumía que las impresiones que ahondaban en el "mole celebro de los Niños", así como la buena educación, eran imborrables. Por lo que raramente, un niño ilustrado en las máximas de la religión y de la política, podría ser persuadido por "las Fábulas que les quentan los viejos, y finados". Además, se consideraba que la diversidad de lenguas naturales era motivo de desunión, por lo que el aprendizaje del castellano era considerado como medio para estrechar "laso de amistad". En la misma década, un autor anónimo observaba que los indios mantenían algunas idolatrías, por medio del idioma, en cuentos y cantares. Además, consideraba que de la supervivencia de las lenguas indígenas se seguía un perjuicio político, pues "por medio de los cantares y cuentos conservan muchas idolatrías y fantásticas grandezas de sus antepasados, de que resulta aborrecer á los españoles, mirándolos como á unos tiranos y única causa de sus miserias" (Concolorcorvo 1942: 307 [1773]. En el tono serio de un arbitrista, proponía que se pusiese "el mayor empeño para que olvidasen enteramente su idioma natural".

Estas posiciones se divulgaban en un período en el que la monarquía asumía una decidida voluntad de castellanización de las poblaciones indígenas a través de la instalación de escuelas de primeras letras, en el conjunto de los pueblos de indios, cuyo propósito era fomentar la enseñanza del castellano, y la eliminación de las lenguas nativas, para lograr la instrucción y civilidad de los indios. Aunque la cédula de 1770 recogía orientaciones y proyectos que se habían esbozado entre los siglos XVI y XVII, sin embargo abrió una nueva coyuntura en las políticas coloniales y en las dinámicas regionales y locales, y contaba, además, con funcionarios civiles y eclesiásticos que compartían ampliamente la voluntad aculturadora que se observa en el ciclo borbónico. Tanck de Estrada ha sostenido que el arzobispo Lorenzana había impulsado una política de castellanización, en Nueva España, bajo la convicción de "que la diversidad de lenguas era peligrosa para la estabilidad y seguridad del gobierno" (Tanck de Estrada 1999: 174). Gruzinski ha visto en este proyecto de castellanización "un instrumento de consolidación del Estado en detrimento de la Iglesia y de los súbditos 'americanos"” (Gruzinski 1993: 269). En una perspectiva más global, y más afín a la alta burocracia imperial, se puede sostener que el proyecto de castellanización, y de eliminación de las lenguas indígenas, estaba en correspondencia con un desplazamiento tanto en el paradigma político como en el paradigma evangelizador que hasta entonces había orientado el proyecto imperial (Hidalgo y Castro 2007: 48-56). Estos procesos se han conceptualizado como una "reconquista" y como una "segunda aculturación", aunque ambos se encuentran estrechamente vinculados dada la subordinación de la iglesia al estado colonial ${ }^{59}$.

La audiencia de Charcas encargó al obispo de La Paz Gregorio de Campo (1765-1789) la implementación de este proyecto, recogiendo la indicación del fiscal que la ejecución de la cédula debía ser cumplida por los prelados y curas doctrineros (Hidalgo y Castro 2007: 50). Aunque el obispo parecía estar consciente de las dificultades que surgirían de la instalación de escuelas de primeras letras en los pueblos de indios, no obstante él tenía la convicción que dichos establecimientos alentarían la castellanización y la subsecuente eliminación de las lenguas indígenas. Situación que había observado en el virreinato de Nueva Granada, en el que había sido dean de la arquidiócesis de Santa Fe, "en donde se ha extinguido enteramente el ydioma nativo de aquellos naturales: de suerte, que a excepcion de sola una provincia, en que según oi decir, conserban los yndios su lengua materna para tratar entre si los negocios, que quieren ocultar de los curas, y de los españoles"60. De acuerdo al obispo, esto conllevó también a la eliminación del requisito de examen de lengua para otorgar el beneficio a los curas doctrineros. Además, el obispo consideraba que la castellanización se había producido "porque los antiguos se aplicaron a introducir, y hacer vulgar la lengua castellana, y si lo propio huvieran executado en este continente sin duda huvieran conseguido el mismo efecto"61.

El proyecto del obispo contempló la fundación, en cada pueblo, de una escuela pública en la que separadamente debía enseñarse a leer en castellano a niños y niñas respectivamente, la enseñanza de la doctrina cristiana en dicho idioma y la prohibición que el maestros o los escolares hablasen entre sí un idioma nativo. Junto a esto, se proponía un método para la enseñanza del castellano, que consistía en repetir, en las mañanas y tarde, las voces más comúnmente utilizadas para explicar las cosas por sus propios nombres, debiendo el maestro hacerles entender la correspondencia con su legua 
nativa. Por otra parte, se ordenaba que en las casas y haciendas de españoles se hablase únicamente castellano. Retomando lo dispuesto en las Leyes de Indias, se prescribía que para la designación de las autoridades indígenas (caciques, segundas, hilacatas, alcaldes, fiscales y mandones) estas debían saber castellano y, en este idioma, aquellas debían llevar todos los asuntos propios de los diferentes cargos. Para evitar que la enseñanza de la doctrina en la iglesia no encontrase inconvenientes, ya que el desconocimiento del castellano y la rudeza de los indios se estipuló que aquella fuese enseñada en lengua aymara o quechua para que los indios entendiesen con más facilidad la equivalencia de la voces en una u otra lengua. Tras la finalización de la doctrina, el doctrinero debía también hacer repetir, a la concurrencia, los nombres propios de las cosas eclesiásticas, espirituales, temporales y domésticas con el mismo propósito que se debía hacer en las escuelas. Por último, el obispo encargaba al corregidor la vigilancia del cumplimiento de estas disposiciones y a los curas el cumplimiento de lo que les estaba encargado, trabajando entre ellos de común acuerdo ${ }^{62}$.

El fiscal de la audiencia de Charcas Thomas Álvarez y Acevedo mostró extrañeza por el poco efecto que habían tenido las diversas disposiciones reales castellanizantes en el distrito de la audiencia. Álvarez y Acevedo agregaba que eran escasos los indios que hablaban castellano tanto en ciudades como La Plata y La Paz, o en villas como Potosí, Oruro o Cochabamaba, así como en las provincias más remotas y retiradas de la audiencia. A juicio del fiscal, el desconocimiento del castellano impedía que los indios fuesen instruidos en los principios de religión y política, dificultándoseles el trato y comercio con los españoles, pero también que tratasen sin intérpretes sus propios negocios en los tribunales. Esto último redundaba en serios problemas desde el costo económico de los intérpretes hasta la poca claridad de las interpretaciones que embarazaba el trabajo de los jueces y del propio protector fiscal -como el mismo Álvarez lo había experimentado, por algún tiempo, en la subrogancia que había realizado en este último cargo-. El fiscal compartía el expandido juicio que el desconocimiento del castellano estaba en la raíz del escaso logro de la civilidad y la política entre los indios. La civilidad y la política estaban estrechamente vinculadas a la sociabilidad, urbanidad y policía (el buen orden y cumplimiento de disposiciones y ordenanzas) que debía observarse en el comportamiento de los hombres que viven civilmente. Esta situación provocaba la incivilidad, los vicios y los errores que dominaban en la mayor parte de los indios, pero también en la desconfianza que estos tenían en su trato con los españoles, provocándose perjuicios mutuos pero que repercutían en el servicio al rey y en la tranquilidad, buen orden y felicidad que debían observarse en sus dominios. Pero la supervivencia de la incivilidad no podía ser atribuida a la nula disposición de los indios a la enseñanza, sino que precisamente a lo extendido que se encontraba esta vulgar objeción, particularmente entre ministros inferiores. De ahí que el fiscal propusiese que se estableciese escuelas de primeras letras en todos los pueblos de indios bajo la jurisdicción de La Plata, de acuerdo con un plan que dirigió a la audiencia ${ }^{63}$.

La audiencia de La Plata recogió la propuesta del fiscal Thomás Álvarez, y los arbitrios del obispo Gregorio de Campo, y despachó provisiones circulares a los corregidores y curas doctrineros del distrito en las que ordenaba el establecimiento de escuelas para que los indios aprendiesen a leer, escribir y hablar el castellano. Con esta medida los miembros de la audiencia esperaban desterrar "las diversas lenguas de los yndios, que impiden, y embarazan su instrucción [y] civilidad y correspondencia con los españoles" ${ }^{64}$. A pesar que el auto de la audiencia fijó un plazo de cuatro meses para que las autoridades locales formalizaran las escuelas, sin embargo su implementación fue lenta. Pero también hubo corregidores que implementaron rápidamente esta propuesta, particularmente en el área del obispado de La Paz. El corregidor de la provincia de Chayanta ejecutó dicha medida en julio de 1773, siguiendo las indicaciones del obispo Gregorio de Campo en lo referido a la organización de la enseñanza. La audiencia recomendó que se considerasen las medidas del corregidor de Chayana en aquellas provincias en que aún no se ejecutaban las medidas. No obstante, los esfuerzos seguían siendo insuficientes en la implementación de escuelas de primeras letras en los demás pueblos de indios. Hacia 1775 la audiencia de La Plata volvió a insistir en este punto, exigiendo que los corregidores diesen cumplimiento a la provisión bajo pena de multas y de cuantiosas imposiciones $^{65}$. En gran medida el cumplimiento de esta disposición se encontraba obstaculizada por la falta de medios para implementar las escuelas, de 
acuerdo con los informes emitidos por los curas doctrineros de varias provincias, y, en algunas de estas, como Carangas, la provisión real ni siquiera había llegado ${ }^{66}$.

En sus informes curas y corregidores compartían que el establecimiento de escuelas, y el subsecuente aprendizaje del castellano, permitiría desterrar los nocivos efectos que tenía la supervivencia de las lenguas indígenas, estableciendo "la civilidad de sus yndiuiduos, como la mas clara noticia de nuestra santa fe catholica" 67 . Para varios de estos funcionarios provinciales, el desconocimiento del castellano permitía, entre otras aprensiones y extravagancias de los indios, la supervivencia de la superstición y la incomprensión del verdadero concepto de la religión, como lo señalaba el corregidor de la provincia de Carangas ${ }^{68}$. Además, estos funcionarios compartían la noción que la instrucción permitiría que los indios "se civilizaran en los docmas de nuestra santa fe catholica y se evitara que vivan muchos de ellos bagantes y poco menos que gentiles", como lo declaraba el corregidor de San Pedro de Atacama Francisco de Argumaniz ${ }^{69}$.

La renovación del programa de castellanización de las poblaciones indígenas se planteaba en un período en que la iglesia colonial debatía nuevas orientaciones en sínodos y concilios provinciales. El sínodo del arzobispado de La Plata recogió la representación que vinculaba las lenguas indígenas con la supervivencia de un registro gentílico, promovido por sujetos supersticiosos que identificaba entre los amautas. De acuerdo a la disposición sinodal, éstos aprovechaban la embriaguez de juntas y bailes para traer "a la memoria a los demas sus ritos gentilicos con relacion circunstanciada de sus huacas, excitandolos a su veneracion, y culto con ceremonias, y canticos lugubres a su vsanza, y en la lengua general, o materno a este efecto"70. En el II Concilio Platense (1774-1778), la iglesia platense asumió la orientación castellanizante bajo el postulado que "el idioma de cualquier nación deba ser el de su soberano", agregando que, en la provincia de La Plata, el castellano debía ser "la única, universal y pública lengua viva de todos los vasallos de su Magestad católica" (Castañeda y Hernández 2007: 641).

Hasta el momento no se cuenta con documentación que permita analizar sistemáticamente la recepción que esta política de castellanización tuvo entre las diversas comunidades de indios.
Algunas comunidades reclamaron la ausencia de escuelas y de preceptores con el claro propósito de dejar entrever el incumplimiento de sus caciques, como es el caso de los comuneros de la doctrina de Charazani de la provincia de Larecaja. Para las autoridades virreinales, esta situación reflejaba la omisión del cura de la doctrina, que se extendía también a otros de la diócesis, más preocupado de "cuidar de obenciones, y engrosar las utilidades" que atender a sus obligaciones pastorales -entre ésta proveer de maestro entre los indios asignados al servicio de la iglesia ${ }^{71}$. Pero en otras comunidades, los indios principales alentaron, de común acuerdo con sus curas doctrineros, el nombramiento de preceptor o maestro escolero. Los principales del pueblo de Azángaro solicitaron al cura doctrinero que nombrase como maestro a don Blas Raymundo de Ylaricona, bajo la consideración de ser "persona apta, y bien instruida en escriuir, como en la aritmethica, y demas expedientes que se practican, asi por su buena conducta, e ynteligencia, como su notoria homradez"72. No obstante, en otros casos los comuneros alegaron pobreza para negarse contribuir al pago del maestro de escuela, sin embargo señalaban que "en sus casas educaban a sus hijos ${ }^{73}$. Esta observación no parece una mera excusa, y parece que esta enseñanza doméstica se mantuvo en algunas zonas, incluso en áreas tan lejanas como el pueblo de Belén de Susquez. A principios del siglo XX, un contemporáneo señalaba su sorpresa por el conocimiento que algunos indios tenía de la escritura en español, careciendo los indios del lugar de escuela. De acuerdo al testimonio, para los miembros de la familia del capitán Victoriano se trataba de una práctica transmitida de padre a hijos, pues su bisabuelo lo había aprendido en San Pedro de Atacama (Boman 1908; 2: 440).

\section{Observaciones finales}

En la segunda mitad del siglo XVI, las lenguas generales adquirieron carta de prestigio en el terreno administrativo y pastoral. El propio virrey Toledo otorgó al quechua, puquina y aymara el carácter de lenguas generales; lo propio hizo el III Concilio Limense con el quechua y el aymara. La iglesia de Charcas consideró al aymara, quechua, puquina y uroquilla, como lenguas generales para el adoctrinamiento de los indios. Sin embargo, privilegió la prédica en aymara en aquellas doctrinas en las que se hablaba más de una lengua. No obstante, 
desde la década de 1580 esta postura experimentó algunos tensiones provocadas por disposiciones reales inspiradas en sectores proclives a la castellanización de las poblaciones indígenas.

Aunque la tendencia castellanizante mantuvo firmes partidarios entre algunos miembros de la burocracia imperial, sin embargo las dificultades prácticas que experimentaron las tempranas medidas de castellanización, y la orientación pastoral en lengua general que dominó en la iglesia colonial, postergaron un proyecto que solo conoció una renovación hacia la década de 1770 . La castellanización precisaba de escuelas de primeras letras que no se extendieron con sistematicidad en los pueblos de indios. Incluso en un período tan propicio como la coyuntura administrativa abierta por la cédula de 1770, la implementación de aquellas escuelas fue obstaculizada por la carencia de cajas de comunidad que pudieran financiarlas. No obstante, se esbozaron proyectos de escuelas castellanizantes en las décadas de 1630, 1680, 1690, 1730 y 1770. La documentación disponible no permite avanzar mayores consideraciones respecto del funcionamiento de estas escuelas, con excepción de algunas experiencias de la década de 1770 que se ha analizado en otro trabajo. Junto con este aspecto queda por investigar la dimensión social que caracterizó a las escuelas de primeras letras en los pueblos de indios.

Si bien la iglesia virreinal mantuvo la orientación pastoral de adoctrinar en lenguas generales, sin embargo no se trató de una posición homogénea. Lo que puede evidenciarse en la posición que observaron algunos obispos de La Paz en las décadas antes señaladas. Posición que no solo contrastó con la mantenida por la autoridad arzobispal de La Plata, sino que incluso con la de los miembros de los cabildos eclesiásticos. La documentación presentada permite plantear que estas posiciones contrapuestas se originaron en algunos conflictos derivados de la acción episcopal: el más evidente fue el interés de los obispos y arzobispos de otorgar beneficios eclesiásticos a su parentela, cuyos miembros desconocían mayoritariamente las lenguas generales. Pero no puede descuidarse que las autoridades eclesiásticas formaban parte de redes en las que circularon discursos y representaciones, entre otros, respecto de los curas doctrineros y de las poblaciones indígenas. Se ha llamado acá la atención que los prelados de principios del siglo XVII compartieron un juicio crítico sobre los doctrineros responsabilizándolos del estado en que se encontraba el adoctrinamiento de los indios. En gran medida, estos prelados sostuvieron que la permanencia de la idolatría se ocasionaba por el insuficiente trabajo pastorales de los curas doctrineros.

Pero hubo algunos que sostuvieron que la supervivencia de idolatrías y supersticiones era ocasionada por la permanencia de las lenguas indígenas. En estas posiciones, se sostuvo una estrecha relación entre lengua indígena y registro gentílico, además, de negar que en aquellas lenguas se pudiese traducir los conceptos teológico-pastorales. No obstante, a pesar de algunas voces disonantes y esporádicas, tendió a primar la idea que las lenguas generales, particularmente el quechua y el aymara, eran vehículos clave en el adoctrinamiento y evangelización de los indios.

Hacia la segunda mitad del siglo XVIII, entre los funcionarios civiles y eclesiásticos se evidenció una fuerte tendencia castellanizante. Si hacia la década de 1730 el fiscal del Consejo había considerado una novedad el proyecto del obispo de La Paz respecto de prohibir el uso de las lenguas indígenas, en la década de 1770 este tipo de proyectos proliferó entre funcionarios de distintas jerarquías. Curas doctrineros, corregidores y prelados participaron activamente en los esfuerzos por establecer escuelas castellanizantes que alentasen la eliminación de las lenguas indígenas e incorporasen a los indios a la civilidad. El viejo paradigma salvífico que había animado a la iglesia misionera era desplazado por el énfasis en el fomento de las poblaciones y la felicidad de los súbditos. Pero no debe descuidarse que la iglesia adhirió al discurso castellanizante en la medida que confiaba en que la civilidad de los indios redundaría en una menos dificultosa actividad pastoral. No sin razón prelados como el obispo de La Paz se mostraron firmes partidarios de la castellanización. Pero también la castellanización quitaba peso a la obligatoriedad que los doctrineros dominasen las lenguas indígenas, dejando la puerta abierta para que dichos cargos fuesen ocupados por familiares y allegados de obispos y arzobispos. 


\section{Referencias Citadas}

Acosta, J. de

1987 [1576] De procuranda indorum salute. Volumen II, Consejo Superior de Investigaciones Científicas, Madrid.

Álvarez, B.

1998 [1588] De las costumbres y conversión de los indios del Perú. Memorial a Felipe II (1588), edición de M. Martín, J. Villerías y F. del Pino. Ediciones Polifemo, Madrid.

Avendaño, F. de

1649 Sermones de los Misterios de nuestra Santa Fe Católica, en lengua castellana y la general del inca. Jorge López Impresor de Libros, Lima.

Aldrete, B. de.

1606 Del origen y principio de la lengua castellana ó romance que oi se vsa en España. Carlo Willeto, Roma.

Alfaro, C.

2001 Política lingüística colonial hispánica, catequesis y castellanización. Anuario brasileño de estudios hispánicos, 11: 39-52.

Bernal, A.M.

2007 Historia de España. Monarquía e Imperio, volumen 3, editado por J. Fontana y R. Villares. Crítica-Marcial Pons, Barcelona.

Boman, É.

1908 Antiquités de la région andine de la république Argentine et du désert d'Atacama. volumen 2, Impremerie Nationale, París.

Bouysse-Casagne, Th.

1987 La identidad aymara. Aproximación histórica (siglos $X V$-XVI). HISBOL, La Paz.

Brading, D.

1993 Orbe Indiano. De la monarquía católica a la república criolla, 1492-1867. Fondo de Cultura Económica, México. 1994 Una iglesia asediada: el obispado de Michoacán, 1749-1810. Fondo de Cultura Económica, México.

Breva-Claramonte, $\mathrm{M}$.

2008 El marco doctrinal de la tradición lingüística europea y los primeros misioneros de la Colonia. Bulletin Hispanique, tomo 110, 1: 25-59.

Burke, $\mathrm{P}$.

2006 Lenguas y comunidades en la Europa moderna. Editorial Akal, Madrid.

Calvet, J.

2005 Lingüística y colonialismo. Breve tratado de glotofagia. Fondo de Cultura Económica, México.

Castañeda, P. y Hernández, P.

2007 El II Concilio de la Plata (1774-1778). Editorial Deimos, Madrid.

Castro, N. J. Chacama y R. Mir

2009 Excitar y subyugar. Pastoral de la imagen y poblaciones indígenas en Arica Colonial. En Diálogo Andino 34: 25-43.

Castro, N.; Hidalgo, J. y Briones, V.

2014 Fiestas, borracheras y rebeliones. En Historia Andina en Chile, vol. II Políticas imperiales, dinámicas regionales y sociedades indígenas, editado por J. Hidalgo et al., pp. 250-280. Editorial Universitaria, Santiago.

Castro, N. e Hidalgo, J.

2014 El proyecto de castellanización del obispo Pedro de Perea (Obispado de Arequipa, 1620), ponencia presentada en I Jornada Estudiantil de Historia Colonial UV, Instituto de Historia y Ciencias Sociales, Universidad de Valparaíso, 4 de noviembre de 2014.

Cerrón-Palomino Rodolfo

2016 El lenguaje como hermenéutica en la comprensión del pasado: a propósito del Puquina en la génesis del imperio incaico. Diálogo Andino No 49: 11-27.

Certeau, M.; Julia, D. y Revel, J.

2008 [1975] Una política de la lengua. Universidad Iberoamericana, México.

Concolorcorvo

1942 [1773] El Lazarillo de Ciegos Caminantes. Desde Buenos Aires hasta Lima. Ediciones Argentinas Solar, Buenos Aires.

Cortés, J.

1987 El catecismo en pictogramas de Fr. Pedro de Gante. Fundación Universitaria Española, Madrid.

Crevels, M. y Muysken P. ( edit.)

2009 Lenguas de Bolivia. Tomo I Ámbito Andino. Plural Editores, La Paz.

Domínguez, N.

2010 Para una cartografía de la lengua puquina en el Altiplano colonial (1548-1610). En Boletín de Arqueología PUCP, 14: 309-328.

Durston, A.

2007 The History of Christian Translation in Colonial Peru,1550-1650. University of Notre Dame Press, Notre Dame, Indiana.

Duviols, $\mathrm{P}$.

2003 Procesos y visitas de idolatrías. Cajatambo, siglo XVII. PUCPe Fondo editorial-IFEA, Lima.

Encinas, D. de

1945 [1596] Cedulario Indiano, reproducción fascímil de la edición única de 1596, estudio e índice de Alfonso García Gallo. Ediciones Cultura Hispánica, Madrid.

Enciso Contreras, J. (coord.)

2005 Cedulario de la Audiencia de la Plata de los Charcas (siglo XVI).

Espinoza Soriano, W.

1980 Los fundamentos lingüísticos de la etnohistoria andina y comentarios en torno al anónimo de Charcas de 1604. Revista Española de Antropología, pp. 149-181.

Fernández de Villalobos, G.

1990 [1683] Estado eclesiástico, político y militar de América (o grandeza de Indias), edición y estudio preliminar de Javier Falcón Ramírez. Instituto de Cooperación IberoamericanaSociedad Estatal Quinto Centenario-Instituto de Estudios Fiscales, Madrid.

Garcilaso de la Vega, I.

2006 Comentarios Reales. Editorial Porrúa, México.

González, S.

2014 Del Génesis a los Andes: Una lectura del Diluvio y las cronologías del Incario a través de las crónicas (siglos XVI$X V I I)$, Tesis de Doctorado en Filología Española, Departamento de Filología Española, Universidad Autónoma de Barcelona.

Groupe de recherches sur les missions ibériques modernes 1999 Politiques missionnaires sous le pontificat de Paul Paul IV. Un documente interne de la Compagnie de Jésus en 1558. Mélanges de l'école française de Rome, vol. 111, 1: 277-344. 
Gruzinski, S.

1985 La segunda "aculturación": el estado ilustrado y la religiosidad indígena en Nueva España (1775-1800). Estudios de Historia Novohispana, VIII: 175-200.

1993 La colonización de lo imaginario. Poblaciones indígenas y occidentalización en el México colonial. Fondo de Cultura Económica, México.

Hanke, L.

1978 Perú. Los virreyes españoles en América durante el gobierno de la casa de Austria, BAE. Atlas, Madrid.

Helm, F.

2002 La misión católica durante los siglos XVI-XVII: contexto y texto. UCB-Verbo Divino-Editorial Guadalupe, Cochabamba.

Hidalgo, J.

2004 [1984] Descomposición cultural en el siglo XVIII: lengua, escuela, fugas y complementariedad ecológica. En Historia Andina en Chile, pp. 157-184. Editorial Universitaria, Santiago.

Hidalgo, J. y Castro, N.

2007 Civilización y castellanización de las poblaciones indígenas. Audiencia de Charcas, 1770-1780. En La circulación en el mundo andino, 1760-1860, editado por Teresa Pereira y Adolfo Ibáñez, pp. 43-79. Fundación Mario Góngora, Santiago.

Hoyo, J. del

1917 [1772] Estado del Catolicismo, Política y Economía de los naturales del Perú que se dicen indios y medios simplísimos de corregir (1772). En Informaciones acerca de la religión y gobierno de los incas, Segunda Parte, Colección de Libros y Documentos referentes a la Historia del Perú, Tomo IV. Imprenta y Librería San Martín, Lima.

Iannuzi, I.

2008 Talavera y Nebrija: lenguaje para convencer, gramática para pensar. Hispania. Revista española de historia, volumen LXVIII, 228: 37-62.

Lafaye, J.

2005 Por amor al griego. La nación europea, señorío humanista (siglos XIV-XVII). Fondo de Cultura Económica, México.

Levillier, R.

1925 Gobernantes del Perú. Cartas y papeles. Imprenta de Juan Pueyo, Madrid.

Lynch, J.

1996 El reformismo borbónico e Hispanoamérica. En El reformismo borbónico, editado por Agustín Guimerá, pp. 37-59. Alianza Editorial, Madrid.

Mannheim, B.

1991 The Language of the Inka since the European Invasion. University of Texas Press, Austin.

Matienzo, J.

1967 [1567] Gobierno del Perú (1567), edición y estudio preliminar de Guillermo Lohman Villena. Travaux de l'Institut Français d'Études Andines Tomo XI, París-Lima. Méndez de Tiedra, J.

2002 [1619-1620] Constituciones del I Sínodo Platense (1619-1620), transcripción y edición de Josep Barnadas. Archivo-Biblioteca Arquidiocesanos Mons. Taborga, Sucre, Bolivia.

Molina, R. y Albó, X.

2012 Atlas de idiomas y pertenencia a pueblos indígenas y originarios de Bolivia. IBIS-UCB, Plural Editores, La Paz.
Morong, G.

2014 El indio melancólico y temeroso: representaciones del alteridad en dos textos de Indias, Perú colonial siglos XVI-XVII. En Diálogo Andino 45: 27-38.

Nebrija, Antonio

Gramática castellana (Disponible desde: http://bvpb.mcu.es/ es/consulta/resultados_busqueda.cmd?posicion $=12 \&$ form $a=$ ficha\&id=21).

Osorio, I.

1990 La enseñanza del latín a los indios. Universidad Nacional Autónoma de México, México.

Peña, A. de

1771 [1660] Itinerario para parrocos de indios. Oficina de Pedro Marín, Madrid.

Pérez, L.

2009 La creación de las cátedras públicas de lenguas indígenas y la secularización parroquial. Estudios de historia novohispana, 41: 45-78.

Perona, J.

1991 Latina uocabula ex iure ciuili in uoces hispanienses interpretata. II,1, de Elio Antonio de Nebrija. Cahiers de linguistique hispanique médiévale. 16: 189-365.

Ruiz Torres, P.

2008 Historia de España. Reformismo e Ilustración, volumen 5, dirigida por J. Fontana y R. Villares. Crítica-Marcial Pons, Barcelona.

Sánchez-Albornoz, N.

2006 Rumbo a América. Gente, ideas y lenguas. El Colegio de México, México.

Santo Tomás, D. de

1951 [1560] Gramática o Arte de la lengua general de los indios de los reynos del Perú, edición facsimilar de Raúl Porras Barrenechea. Instituto de Historia, Universidad Nacional Mayor de San Marcos, Lima.

Querejazu, R.

1995 Historia de la Iglesia Católica en Charcas (Bolivia). Imprenta Papiro, La Paz.

Saravia Viejo, Ma.

1989 Disposiciones Gubernativas para el Virreinato del Perú, 1575-1580, tomo II, introducción de Guillermo Lohman Villena, transcripción de María Justina Saravia Viejo. Escuela de Estudios Hispanoamericanos-CSIC-Montes de Piedad y Caja de Sevilla, Sevilla

Solórzano Pereira, J.

1648. Política Indiana.

Subirats, E.

1994 El continente vacío. La conquista del Nuevo Mundo y la conciencia moderna. Siglo XXI Editores, México.

Tank de Estrada, D.

1999 Pueblos de indios y educación en el México colonial, 1750-1821, México, El Colegio de México, 1999.

Taylor, G.

1983 Lengua general y lenguas particulares en la antigua provincia de Yauyos (Perú). Instituto, "Gonzalo Fernández de Oviedo", Consejo Superior de Investigaciones Científicas, Madrid.

2000 Camac, camay y Camasca y otros ensayos sobre Huarochirí y Yauyos. CBC, Cusco.

Vásquez de Espinoza, A.

1992 Compendio y descripción de las Indias Occidentales, edición de Balbino Velasco Bayón. Historia 16, Madrid. 
Vargas Ugarte, R.

Concilios Limenses (1551-1772), Tomo I. Tipografía Peruana, Lima.

Zavala, S.

1996 Poder y lenguaje desde el siglo XVI. Colegio de México, México.

\section{Archivos y fuentes primarias}

Archivo General de Indias (AGI).

Archivo y Biblioteca Nacionales de Bolivia, Sucre (ABNB).

Archivo y Biblioteca Arquidiocesanos de Sucre (ABAS).

Archivo Eclesiástico "Canónigo Felipe López Menéndez", Arzobispado de La Paz.

\section{Notas}

1 Para una visión de conjunto, consúltese Ruiz Torres (2008).

2 Para un estudio de los humanistas europeos, véase Lafaye (2005).

3 La relación del proyecto enciclopédico de Nebrija con Lorenzo Valla ha sido analizada por Perona (1991).

$4 \quad$ En el siglo XVI, se usaron cartillas en latín para el adoctrinamiento de indios, pero tempranamente la iglesia virreinal desestimó esta modalidad. No obstante, el aprendizaje del latín, por parte de los indios, estuvo estrechamente ligado a su capacidad de comprender la teología y de acceder al orden sacerdotal. Sobre este punto, y para el área de Nueva España, consúltese Osorio (1990).

5 Aunque Garcilaso retoma una perspectiva análoga al del imperialismo gramatical, sin embargo, ha señalado Subirats, lo hace transformando ese imperialismo "en una hermenéutica de resistencia y restauración, por medio de aquellos contenidos simbólicos y míticos, y, en definitiva, sociales, inherentes al lenguaje" (Subirats 1994: 239). De este modo, Garcilaso retoma una reflexión humanista según la cual la imposición de una "lengua falsa, una lengua corompida -con mucha razón una lengua impuesta- serían idénticas $[\ldots]$ a un acto de criminal trasgresión de la ley, y un atentado a la conservación de los pueblos" (Subirats 1994: 241).

6 Sebastián de Covarrubias, Tesoro de la lengva castellana, o española, Madrid, Luis Sánchez Impresor, 1611, f. 93 v.

7 Otto Zwartjes, editor, Las gramáticas misioneras de tradición hispánica (siglos XVI-XVII), Amsterdam, Ed. Rodopi, 2000, p. 2. Para un análisis de los supuestos epistémicos en que operó la lingüística misionera en el siglo XVI, consúltese Manuel Breva-Claramonte, "El marco doctrinal de la tradición lingüística europea y los primeros misioneros de la Colonia”, en Bulletin Hispanique, 2008, tomo 110, 1: 25-59.

8 "Instrucciones y constituciones para el adoctrinamiento de los indios del Obispado. 1549-II-14”, AGI Lima 300, foja $1 \mathrm{v}$.

9 Para un análisis de los supuestos epistémicos en que operó la lingüística misionera en el siglo XVI, consúltese BrevaClaramonte (2008).

10 "Carta que su Magestad escriuio al Virrey del Peru año de setenta y siete que ordene lo que mejor le pareciere cerca de que haya en la vniuersidad de los Reyes catedras de lenguas de indios" (Encinas 1945 [1596]: 205). Para una panorama general sobre las cátedras de lengua indígena, consúltese Pérez (2009).

11 "Prouision de las ordenanças que se han de guardar en las catedras de las lenguas de los Indios, que se han de instituyr en la vniuersidad de los Reyes, y en las otras partes donde huuiere audiencias. 1580-IX-1580" (Encinas 1945 [1596] vol. 1: 205-206).
12 "Prouision que manda la orden que se ha de guardar en la ciudad de la Plata de la prouincia de los Charcas, en fundar la Catreda de la lengua de los Indios y ordenancas que ha de auer en ella. 1580-X-23" (Encinas 1945; 1: 215 [1595]).

13 Archivo y Biblioteca Nacionales de Bolivia, Correspondencia Audiencias de Charcas, $\mathrm{N}^{\circ} 25,1581$, foja 1.

14 "Cédula que mada al virrey del Peru que no de licencia a ningun clerigo ni fraile para venir a estos Reynos sino constare auer residido en aquella tierra diez años. 1589-I10" (Encinas 1945; 1: 122 [1596]).

15 AGI Charcas 17, R 1, N 2, 28-II-1591, foja 3v.

16 AGI Charcas 20, R. 15, N 174, foja 1r.

17 AGI Charcas 415, L. 1, f. 161r.

18 AGI Charcas 415, L. 1, foja 161v.

19 "Carta del Conde del Villar a S.M. sobre materias tocantes al Real Patronato y conversión de los Indios. Los Reyes 23 de abril 1588" (Levillier 1925; XI: 110-122).

20 ABNB, Cédulas Reales (ACh), Real Cédula 266, 1596 (Enciso 2005: 583).

21 Silvio Zavala ha destacado que una cédula del mismo tenor, remitida a Nueva España, fue impulsada por sectores interesados en la castellanización de las poblaciones indígenas, pero que este énfasis fue matizado en la resolución final merced de su "maduro olfato político" (Zavala 1996: 51).

22 En esto último, Josepf de Acosta recogía los debates que desembocaron en la política misionera de la Compañía de Jesús sobre el valor del aprendizaje de las lenguas indígenas. Al respecto consúltese, Groupe de recherches sur les missions ibériques modernes (1999).

23 Un análisis de la pastoral del miedo, en los programas murales de las iglesias coloniales, se encuentra en Castro, Chacama y Mir (2009).

24 Para un análisis de las representaciones coloniales sobre la incapacidad de los indios y su vinculación con la legitimación de la sujeción política, consúltese Morong (2014).

25 Francisco de Toledo, "Ordenanzas generales para la vida en común en los pueblos de indios. 6-XI-1575" (Saravia Viejo 1989; II: 251).

26 "Ordenanzas del Virrey Don Francisco de Toledo estableciendo las funciones del intérprete general de los indios en las lenguas Quichua, puquina y Aymara. Arequipa, 10-VIII-1575" (Levillier 1925; VIII: 300).

27 En las relaciones geográficas de la década de 1580, se insiste en la diversidad de lenguas, existente en cada parcialidad, y en el uso extendido de la lengua general entre los principales, pero también en el resto de la población. M. Jiménez de la Espada, Relaciones geográficas de Indias. Perú, Madrid, Tipografía de Manuel G. Hernández, 1881. 
Domínguez (2010) discutió la periodización de este documento, señalando que la composición de esta documentación debe ser analizada en su relación con las dinámicas eclesiásticas y civiles.

Para una descripción y análisis contemporáneo de las lenguas del área andina boliviana, consúltese Crevels y Muysken (2009) y Molina y Albó (2012).

"Carta del Arzobispo de la Plata al Rey, 20-III-1613", Archivo General de Indias, Charcas 135, foja 1r.

30 "Carta del Obispo de los Charcas, 4-3-1597", AGI Charcas 135.

31 "Carta del arzobispo de la Plata, 20-III-1613”, AGI Charcas 135, foja 1v. Cabe destacar que esta posición del arzobispo es concordante con la que mantenían otros mitrados del virreinato respecto de la supervivencia de idolatrías entre los indios. El propio arzobispo Lobo Guerrero había señalado, hacia 1610 y 1611 , el poco provecho que la predica había tenido entre los indios, quienes se encontraban "tan infieles e idolatras como cuando se conquistaron" (Duviols 2003: 103).

32 "Relación de aviso de cosas del seruiçio de Dios nuestro Señor y de su Magestad, 5-III-1621”, AGI Charcas 135.

33 "El obispo de Arequipa funda con muchas razones la conveniencia que los indios aprendan la lengua española. 1620-III-11", AGI Lima 309.

34 Íbidem, foja $2 \mathrm{r}$.

35 AGI Charcas 138, foja 375 v.

36 "Al arçobispo de Lima encargándole de las hordenes convenientes para que los curas y dotrineros de sus diócesis enseñen a los indios desde su pueriçio la lengua española y en ella nuestra santa fee catholica por los ynconbenientes que se siguen de no sauer. 1634-III-2”, AGI Indiferente 421, L 38, foja 37v.

37 AGI Indiferente 421, L 38, foja 38r.

38 AGI Charcas 138, f. 410 v.

39 AGI Charcas 138, f. 411 r.

40 AGI Charcas 20, R15, No 174, f. 1r.

41 AGI Charcas 20, R15, $N^{\circ} 174$, f. 3r.

42 Antonio de Herrera y Toledo, Relación eclesiástica de la Santa Iglesia Metropolitana de los Charcas (1639), edición de Josep M. Barnadas, Archivo y Biblioteca Arquidiocesanos "Monseñor Taborga", Sucre, 1996, p. 65. Barnadas señala, en nota 63, que Herrera se apoyó en su consideración en la cédula de 1634 .

43 "Carta del arzobispo de la Plata. 28-IX-1648", AGI Charcas 135, foja $1 \mathrm{r}$.

44 Actas Capitulares volumen 11 (1649-1651), Archivo y Biblioteca Arquidiocesanos de Sucre, Archivo Capitular, foja 363. Cabe indicar que en el documento de 1604, citado más arriba, se señalaba que el aymara era la lengua de la doctrina de Atacama.

46 "Para que se obseruen las leyes de la Recopilacion, y despacho arriua inserto que trata de que se desponga a los indios en la enseñanza de la lengua española y se ponga escuelas della. 1685-VII-7", AGI Indiferente 431, L.43, fojas $14 \mathrm{v}-18 \mathrm{r}$.

47 AGI Indiferente 431, L. 43, foja $16 \mathrm{r}$.

48 "Para que en las Prouincias del Peru y Nueva Spaña se pongan escuelas y maestros que enseñen a los índios la lengua castellana en las formas y con las circunstancias que se expresan. 1691-V-30”, AGI Indiferente 431, L.43, fojas 207-209v.

49 AGI Charcas 138, f. 757r.

50 "El obispo de la Paz da razon â VM de la Visita general que ha hecho de aquel obispado, con testimonio de ella, y de las confirmaciones y ordenes que ha administrado; e informa assimismo â VM de la persona, y meritos de su Visitador. 6-XI-1725", AGI Charcas 376, foja 2v.

51 "El Obispo de la Paz ynforma a Vuestra Magestad las razones que le asisten para obligar a los yndios deste obispado a que hablen la lengua castellana. 13-I-1733", AGI Charcas 376 , foja $1 \mathrm{r}$.

52 Ibídem, foja $1 \mathrm{v}$.

53 Idem, foja $2 \mathrm{r}$.

$54 \quad$ Ibídem, foja $1 \mathrm{v}$ (al margen).

55 "Informe del obispo de la Paz de la Visita de la diócesis, 1733-IX-7”, AGI Charcas 376, fojas 3r-v.

56 AGI Charcas 397, foja 2r.

57 "El obispo de La Paz pide a VM se entregue el Colegio Seminario a la Compañía de Jesús. 1750-XII-24", AGI Charcas 376, foja 2r. El fiscal del Consejo fue de opinión que el Seminario no fuera entregado a la Compañía, pero sí que sus miembros pudiesen colaborar como cualquier sacerdote seglar en la formación de los seminaristas.

58 "Al arzobispo de Charcas para que informe reservadamente sobre la falta de sujeto idóneo, que se encargue de la instrucción, y enseñanza de los colegiales del Seminario de la Yglesia Cathedral de la ciudad de La Paz. Aranjuez, 10-VI-1752", Archivo y Biblioteca Arquidiocesano de Sucre, Archivo Capitular Reales Cédulas, volumen 6, folios 35-36.

59 Para una caracterización del "nuevo estado" de la reconquista, véase (Brading 1993: 503-52999). La relación de este nuevo estado con las poblaciones indígenas, particularmente con su religiosidad, ha sido conceptuado como una "segunda aculturación" (Gruzinski 1985). Brading ha sostenido que, en el caso de la jerarquía eclesiástica, se puede visualizar, en esta crítica a las devociones barrocas de los indígenas, el predominio de una "iglesia cristiana" (Brading 1993: 530-552; 1994: 170-191; 1994: 170-191). Para el caso del espacio andino, consúltese la síntesis de Garavaglia y Marchena (2005: 31-83).

60 "Carta del obispo Gregorio de Campo. Mecapaca, agosto 2 de 1773”, Archivo Eclesiástico "Canónigo Felipe López Menéndez,, Arzobispado de La Paz, Autos y Providencias 1766-1790, s/f.

61 "Carta del obispo Gregorio de Campo. Mecapaca, agosto 2 de 1773”, Archivo Eclesiástico "Canónigo Felipe López Menéndez”, Arzobispado de La Paz, Autos y Providencias 1766-1790, s/f.

62 "Carta del obispo Gregorio de Campo a don Antonio del Castillo, corregidor de la provincia de Pacaxes. Mecapaca, 4-VII-1771", Archivo Eclesiástico "Canónigo Felipe López Menéndez”, Arzobispado de La Paz, Autos y Providencias 1766-1790, s/f.

63 "Traslado de los autos del fiscal de la Audiencia de Charcas sobre la cédula de 10 de mayo de 1770. La Plata, 22-XI1772", Archivo Eclesiástico "Canónigo Felipe López Menéndez”, Arzobispado de La Paz, Autos y Providencias 1766-1790, s/f.

64 "Auto de la Real Audiencia de La Plata sobre establecimiento de escuelas en los pueblos de indios del distrito. La Plata, 
9-II-1773”, Archivo Eclesiástico “Canónigo Felipe López Menéndez”, Arzobispado de La Paz, Autos y Providencias 1766-1790, s/f.

65 AGI Charcas 531, foja $18 \mathrm{v}$.

66 Sobre los informes de curas y corregidores de las provincias de Carabaya, Tarijas, Chichas y Carangas, consúltese (Hidalgo y Castro 2007: 63-78). Para el caso de Atacama, Hidalgo (2004 [1984]).

67 "Informe del cura de Carabaya", ABNB Expedientes Coloniales 1773, $\mathrm{N}^{\mathrm{o}} 22$, foja $18 \mathrm{r}$.

68 "Expedientes sobre que se erijan escuelas y se prohíban los diferentes idiomas que se usan", ABNB Expedientes Coloniales Adiciones 1777, $\mathrm{N}^{\circ} 27$, foja 10v.

69 "Testimonio del expediente que se comicionó a don Josef María Paniagua para la averiguación y pacificación del tumulto acaesido en la provincia de Atacama en el asiento de Ingaguasi por el año de 1775", AGNA Interior, legajo 6 , expediente 8 , foja 8r. Este documento se encuentra publicado en Castro, N. et al. (2014). Para el establecimiento de escuelas en la provincia colonial de Atacama, consúltese Hidalgo (2004).

70 "Constituciones Sinodales del Arzobispado de La Plata", ABNB Expedientes Coloniales 1773, № 77, foja 66.

71 "Traslado del ynforme del Contador de Retazas. Lima, 12XII-1775”, Archivo Eclesiástico "Canónigo Felipe López Menéndez”, Arzobispado de La Paz, Autos y Providencias 1766-1790, s/f.

72 "Expediente formado, ante el Fiscal Promotor General, por Blas Raimundo de Hilaricona, indio noble, vecino del pueblo de Asangaro, maestro de escuela de niños naturales y notario eclesiástico, contra el corregidor por excesos", ABNB Expedientes Coloniales Adiciones 1773, $N^{\circ}$ 50, folio $1 \mathrm{r}$.

73 "Expedientes sobre que se erijan escuelas y se prohíban los diferentes idiomas que se usan", ABNB Expedientes Coloniales Adiciones 1777, $\mathrm{N}^{\circ}$ 27, folio 7v. 